\title{
Aerosol Radiative Forcing Estimation over a Remote High-altitude Location ( 4900 masl) near Yala Glacier, Nepal
}

\author{
Mukesh Rai ${ }^{1,2}$, Parth Sarathi Mahapatra ${ }^{2}$, Chaman Gul ${ }^{2,3,4}$, Rijan Bhakta Kayastha ${ }^{1}$, \\ Arnico K. Panday ${ }^{2}$, Siva Praveen Puppala ${ }^{2 *}$ \\ ${ }^{1}$ Department of Environmental Science and Engineering, Kathmandu University, Dhulikhel 42500, Nepal \\ ${ }^{2}$ International Centre for Integrated Mountain Development (ICIMOD), Kathmandu 44700, Nepal \\ ${ }^{3}$ State Key Laboratory of Cryosphere Science, Northwest Institute of Eco-Environment and Resources, Chinese Academy \\ of Sciences, Gansu 73000, China \\ ${ }^{4}$ University of Chinese Academy of Sciences, Beijing 100049, China
}

\begin{abstract}
In the present study, we estimated the aerosol radiative forcing and heating rates near Yala Glacier, Nepal $\left(28.21^{\circ} \mathrm{N}\right.$, $\left.85.61^{\circ} \mathrm{E} ; 4900 \mathrm{masl}\right)$, using in situ black carbon (BC) mass concentration measurements, satellite data sets, and model simulations. The real-time ambient BC mass concentration was continuously measured using an Aethalometer (AE-33) from October 2016 to May 2017. The Optical Properties of Aerosols and Clouds (OPAC) model was used to simulate the aerosol optical properties in conjunction with the in situ measurements and satellite data sets. Outputs from OPAC and the satellite data sets were used as inputs for the Santa Barbara Discrete Ordinate Radiative Transfer Atmospheric Radiative Transfer (SBDART) model to estimate the radiative forcing. The in situ measurements showed that the BC mass concentration peaked during the pre-monsoon season $\left(707.9 \pm 541.8 \mathrm{ng} \mathrm{m}^{-3}\right)$, which was corroborated by the higher aerosol optical depth (AOD) values during this season $(0.058 \pm 0.002)$. The diurnal cycle of the $\mathrm{BC}$ mass concentration exhibited a night-time low and afternoon high, which were influenced by the boundary layer dynamics and valley wind flow pattern. The Concentration Weighted Trajectory (CWT) analysis indicated diverse source regions, including northern Asia, the Indo-Gangetic Plain (IGP), and parts of Nepal and Bangladesh. The Moderate Resolution Imaging Spectroradiometer (MODIS)-derived AOD and Ångström exponent (AE), and the OPAC-simulated single-scattering albedo (SSA) and asymmetry parameter (AP) over the study site were estimated to be $0.048 \pm 0.009$ and $1.32 \pm 0.01$, and $0.938 \pm 0.019$ and $0.710 \pm 0.042$, respectively, during the study period. The mean radiative forcing during the study period for the top of the atmosphere, surface and atmosphere were $3.4,-0.5$ and $3.9 \mathrm{~W} \mathrm{~m}^{-2}$, respectively. Higher atmospheric forcing was observed in the pre-monsoon season, leading to changes in the heating rates.
\end{abstract}

Keywords: Black carbon; Heating rates; Himalayas; OPAC; SBDART.

\section{INTRODUCTION}

Atmospheric aerosols are tiny particles suspended in the earth's atmosphere. Directly, aerosols absorb and scatter the incoming solar and the outgoing terrestrial radiation, thereby affecting the earth's energy budget. Indirectly, aerosols affect the cloud microphysics, altering the cloud albedo through their role as cloud condensation nuclei. Upon deposition on snow or ice, aerosols reduce the surface albedo significantly, resulting in positive radiative forcing (Twomey, 1977; Charlson and Schwartz, 1992; Gul et al., 2018). This effect of aerosols on warming or cooling of the atmosphere is

\footnotetext{
${ }^{*}$ Corresponding author.

E-mail address: SivaPraveen.Puppala@icimod.org
}

expressed in terms of aerosol radiative forcing, or ARF (Haywood et al., 1999). Amidst other aerosols, black carbon (BC) particles are light absorbing and an important short-lived climate forcing agent (Twomey, 1977; Liou, 2002; Ramanathan and Carmichael, 2008). It is emitted as a result of the incomplete combustion of fossil fuels, biofuels, and biomass burning, which have both natural and anthropogenic origins. After carbon dioxide $\left(\mathrm{CO}_{2}\right), \mathrm{BC}$ is recognized as the second-most important climate forcing agent with a total climate forcing of $+1.1 \mathrm{~W} \mathrm{~m}^{-2}$ (Bond et al., 2013; Schmale et al., 2017). Hence, there has been an increased interest in measuring $\mathrm{BC}$ and estimating the ARF using in situ measurements (Badarinath et al., 2004; Nair et al., 2013; Surendran et al., 2013). Several studies in the past have estimated ARF based on in situ measurements in the plain and oceanic regions of the world, but only a few have been undertaken in the glaciated regions (Vinoj et al., 
2004; Moorthy et al., 2005; Marcq et al., 2010). The Himalayas is one such glaciated region of the world, which has been less studied with respect to the impact of aerosols based on in situ measurements. But it is an important source of water and livelihood for approximately 1.4 billion people residing downstream (Viviroli et al., 2007; Immerzeel et al., 2010). The Himalayas also form an orographic barrier, strongly influencing the south-west monsoons. Moreover, the glacier melt in the Himalayas is also accelerated due to surface darkening and atmospheric warming. In this regard, a study by $\mathrm{Xu}$ et al. (2016) indicates that at Tibetan Plateau altitudes, $\mathrm{CO}_{2}$ and $\mathrm{BC}$ concentrations exerted a warming of $1.7^{\circ} \mathrm{C}$ and $1.3^{\circ} \mathrm{C}$ respectively. It concluded that $\mathrm{BC}$, along with $\mathrm{CO}_{2}$, contributes to snow-retreat trends in the region. This situation becomes even grimmer for the Himalayas as it is surrounded by China and India which are two of the largest emitters of various air pollutants in the region (Kopacz et al., 2011; Kaspari et al., 2014). This may also mean accelerated melting of the glaciers. Hence, it is important to analyse the impact of aerosols on glaciers on a fine scale. However, due to difficult terrains and the high logistics cost involved in setting up a monitoring site, only a few studies have estimated the ARF using in situ measurements in the Himalayan region. Considering the above issues, to date, the $\mathrm{BC}$ mass concentration has been measured at only a few high-altitude locations in the Himalayan region. These locations include Hanle (4520 masl) and Meerak (4300 masl) in India, the Nepal Climate Observatory-Pyramid (NCO-P; 5079 masl) in Nepal, and the Qomolangma Atmospheric and Environmental Observation Research Station (QOMS; 4,276 masl) in China (Marcq et al., 2010; Babu et al., 2011; Zhao et al., 2012; Cong et al., 2015; Wang et al., 2016). The forcing estimated at these sites and a few other sites located in the Tibetan Plateau indicates a large variability (Kopacz et al., 2011). Taking into account the scarcity of in situ measurements in highaltitude locations, considerable disparity is also expected in the radiative forcing estimates. Hence, it is essential to undertake more studies over the Himalayan region. In the present study, we calculate the ARF and heating rates near Yala Glacier, Nepal, using in situ BC measurements and outputs from the OPAC and SBDART models constrained by available satellite data sets. In Section 5.1, we discuss the observed $\mathrm{BC}$ temporal variation for a period of 8 months. Section 5.2 analyses the local and regional sources using wind roses, CBPF (concentration bivariate probability function) plots and CWT (concentration weighted trajectory) analysis, while Section 5.3 depicts the meteorological impacts. Section 5.4 deals with the optical properties of aerosols. Finally, in Section 5.5, we discuss the ARF over different surfaces and the heating rates at different elevations.

\section{STUDY SITE}

The International Centre for Integrated Mountain Development (ICIMOD), in partnership with the Department of Environment (DoEnv), Government of Nepal (GoN), set up an autonomous BC monitoring station near Yala Glacier $\left(28.21^{\circ} \mathrm{N}, 85.61^{\circ} \mathrm{E} ; 4900 \mathrm{masl}\right)$ in October 2016 (Fig. 1). A digital elevation model (DEM) was used for describing the topography and observation site as shown in (Fig. 1). The station has been set up with the objective of collecting long-term, real-time $\mathrm{BC}$ mass concentration data at this location in order to enhance the understanding of climate impacts in the long run. Moreover, the study site also allows for improving the understanding of the inflow of pollutants from the plains into the high-altitude locations. The nearest source of any anthropogenic interference is a small village with a cluster of $\sim 50$ households, situated $1 \mathrm{~km}$ below (at an elevation of $3900 \mathrm{masl}$ ) and approximately $4.3 \mathrm{~km}$ south of the observation site. The effects of anthropogenic pollution from this village are rarely expected to show up at the observation site. The landscape around the station is almost flat and is occupied by slight undulations surrounded by grassland and rocks. The seasonal snow cover over the station was observed during the study period. This site is surrounded by mountain peaks and glaciers ranging between elevations 5520 masl and 7234 masl, thus forming a large orographic barrier. The nearest glaciers, Yala and Lirung, are located at an approximate distance of $2 \mathrm{~km}$ and $4 \mathrm{~km}$ north and west of the site respectively. Hence, the measurements at this site could be considered representative of the glaciers in this region, as shown in Fig. 1. The elevation of the Langtang catchment area ranges from 1459 masl to 7213 masl, with an average altitude of 5169 masl and an area of $353.6 \mathrm{~km}^{2}$. Out of the total catchment area, $39 \%$ is covered by glaciers while the remaining $61 \%$ is covered by rocks and vegetation (Pradhananga et al., 2014).

\section{MATERIALS AND METHODS}

\section{Autonomous BC Monitoring Station}

The autonomous BC monitoring station was installed in October 2016 and has been operating to date to monitor realtime $\mathrm{BC}$ mass concentration and meteorological parameters. The $\mathrm{BC}$ mass concentration measurement presented in this study was carried out during October 2016 to May 2017 using a multi-wavelength Aethalometer (AE33; Magee Scientific Co./Aerosol d.o.o, Slovenia) which employs the dual-spot technique for real-time filter loading compensation (Drinovec et al., 2015). It measures the attenuation in the transmitted light at 7 different wavelengths between 370 $\mathrm{nm}$ and $950 \mathrm{~nm}$. The instrument was set up to operate at a constant flow rate of $2 \mathrm{~L} \mathrm{~min}^{-1}$ and the data was recorded at 10-minute intervals. The Aethalometer was factory calibrated and installed for the first time. The BC mass concentration measurement used in the study would represent the changes in optical attenuation at $880 \mathrm{~nm}$ employing the mass absorption cross-section $7.77 \mathrm{~m}^{2} \mathrm{~g}^{-1}$. At $880 \mathrm{~nm} \mathrm{BC}$ is the prime light-absorbing component of the atmosphere (Hansen et al., 1984; Fialho et al., 2006; Drinovec et al., 2015). As it is an autonomous station, the equipment is powered by batteries and is continuously charged by solar panels. The data are then stored in a data logger that has been fitted into a data collector platform (DCP), from which it is remotely transferred via satellite to the central servers at ICIMOD's head office. A schematic representation of the data acquisition and transmission is shown in Fig. S1. 


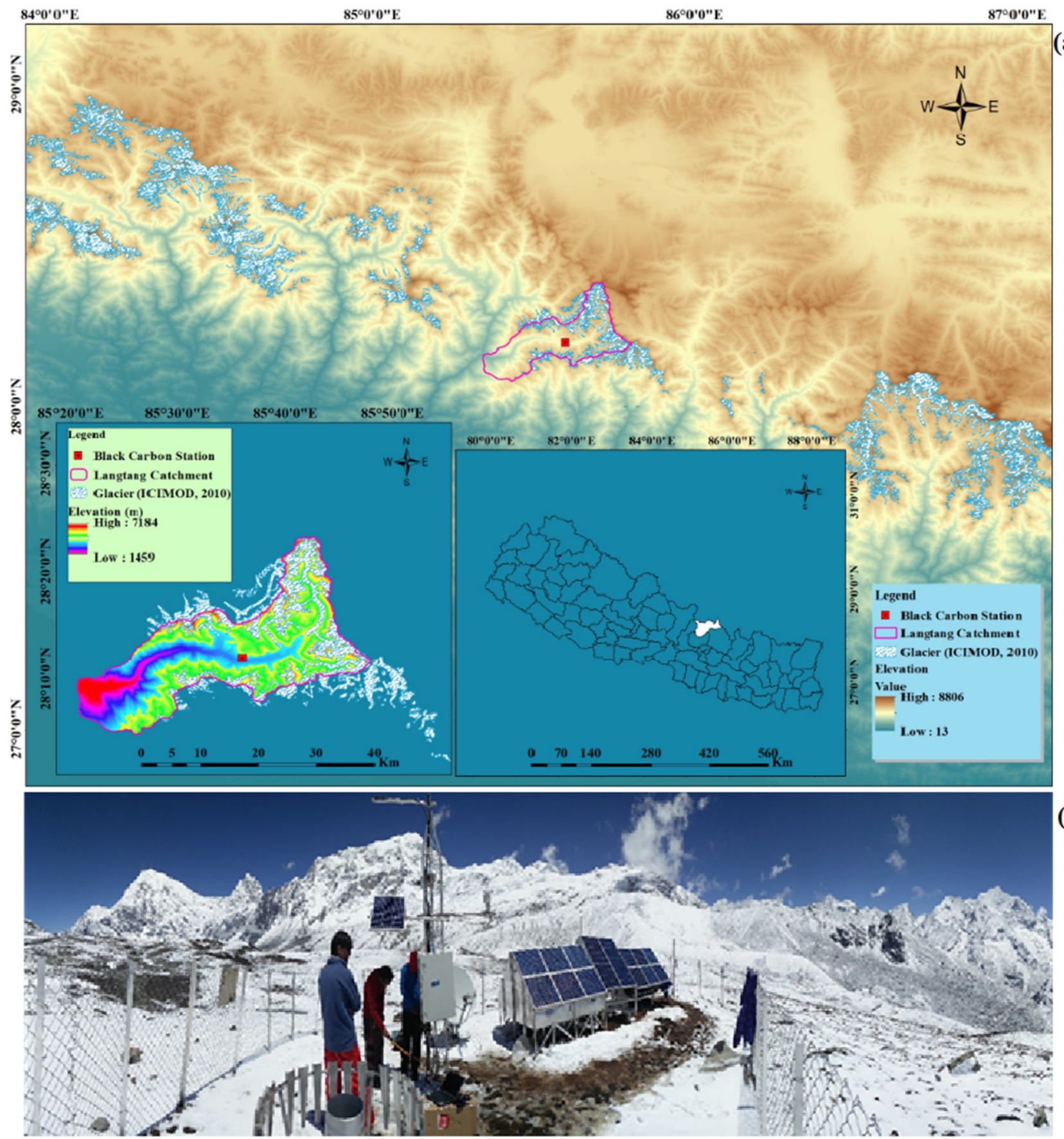

Fig. 1. (a) Map of the study area showing the Himalayan region and the autonomous BC station represented by red square and (b) The autonomous BC station set up near Yala Glacier.

In order to process the Aethalometer data, different types of corrections such as pressure corrections and $\mathrm{C}$-factor corrections (multiple-scattering corrections), as well as the determination of the appropriate mass absorption efficiency value should be carried out. On performing the pressure corrections using standard equations, the BC mass concentration value reduced by $\sim 50 \%$. Thereafter, the $\mathrm{C}$-factor correction depends strongly on the filter substrate and the mixing state of the $\mathrm{BC}$ in aerosols. A value of 2.14 is used for quartz filter (Weingartner et al., 2003) and 1.57 for the TFE-coated glass fibre filter (Drinovec et al.,
2015). In the present case, a value of 1.57 was used by the Aethalometer. However, as the location is situated at a high altitude, it is expected to receive aged ambient aerosols in the absence of any nearby sources. Hence, if we use a correction factor of 4.0 (aged ambient aerosols), it would further reduce the values of the $\mathrm{BC}$ mass concentration by another $\sim 60 \%$ (Schmid et al., 2006). Finally, the location of measurement would also strongly affect the mass absorption efficiency values. As suggested by earlier research, the high-altitude locations in the region have a higher mass absorption efficiency value with an average ranging between 
$9.8 \mathrm{~m}^{2} \mathrm{~g}^{-1}$ to $14.5 \mathrm{~m}^{2} \mathrm{~g}^{-1}$ for Manora Peak and Mount Abu (Ram and Sarin, 2009; Ram et al., 2010). But in the present case, the AE-33 version used a mass absorption efficiency of $7.77 \mathrm{~m}^{2} \mathrm{~g}^{-1}$. Hence, if we further correct the same with the high-altitude values used in other research, it would further reduce the $\mathrm{BC}$ mass concentration values by $\sim 50 \%$, thereby reducing overall the original values by $\sim 90 \%$. Hence, if the present 8-month average $\mathrm{BC}$ values obtained at the observation site $\left(481.5 \pm 273.7 \mathrm{ng} \mathrm{m}^{-3}\right.$; Section 5.1) were reduced by $\sim 90 \%\left(\sim 48 \mathrm{ng} \mathrm{m}^{-3}\right)$, it would not be in line with the annual average values presented in the existing literature $\left(298.8 \pm 341.3 \mathrm{ng} \mathrm{m}^{-3}\right.$ at QOMS; $208 \pm 374 \mathrm{ng} \mathrm{m}^{-3}$ at NCO-P) available for the region. Moreover, similar instruments and methodology have also been used for ambient BC measurements in the nearby high-altitude region (4276 masl) without applying any further corrections (Chen et al., 2018). Considering all the uncertainties associated with the different kinds of corrections, in the present study we have not applied any correction to the instrument-derived data.

\section{Meteorological Measurements}

Meteorological parameters such as temperature, relative humidity $(\mathrm{RH})$, solar radiation, pressure, wind speed, wind direction and precipitation were measured at the site
(Fig. 2). A WS301-UMB Smart Weather Sensor (LUFFT, Fellbach, Germany) was installed for measuring temperature, $\mathrm{RH}$, solar radiation and pressure. Wind direction and wind speed were measured using a Wind Monitor-Alpine (Model 05103-45; Young, Traverse City, MI, USA). A Pluvio ${ }^{2}$ (OTT, Loveland, CO, USA) sensor was installed to measure the intensity and amount of precipitation in liquid and solid forms, which is based on the weighing principle. All sensors were installed at particular heights following World Meteorological Organization (WMO) guidelines. All this equipment has been widely used at high-altitude locations considering the harsh weather conditions (Immerzeel et al., 2014; Shea et al., 2015). The equipment was brand new (factory calibrated) and was installed for the very first time.

\section{Satellite Data Sets}

The Moderate Resolution Imaging Spectrometer (MODIS) on board the Terra and Aqua satellites provides daily global data on aerosol properties using 36 spectral bands ranging from $0.41-14.38 \mu \mathrm{m}$ with spatial resolutions of $0.25,0.5$ and $1 \mathrm{~km}$ at nadir (Levy et al., 2006). In this study, we have used the MODIS Level $23-\mathrm{km}$ aerosol product (Collection 6, MYD04_3K) to retrieve the 550-nm AOD (Levy et al., 2006; Remer et al., 2013) over the Yala Glacier region $\left(28.20^{\circ} \mathrm{S}, 85.60^{\circ} \mathrm{W}, 28.26^{\circ} \mathrm{N}, 85.67^{\circ} \mathrm{E}\right)$. The

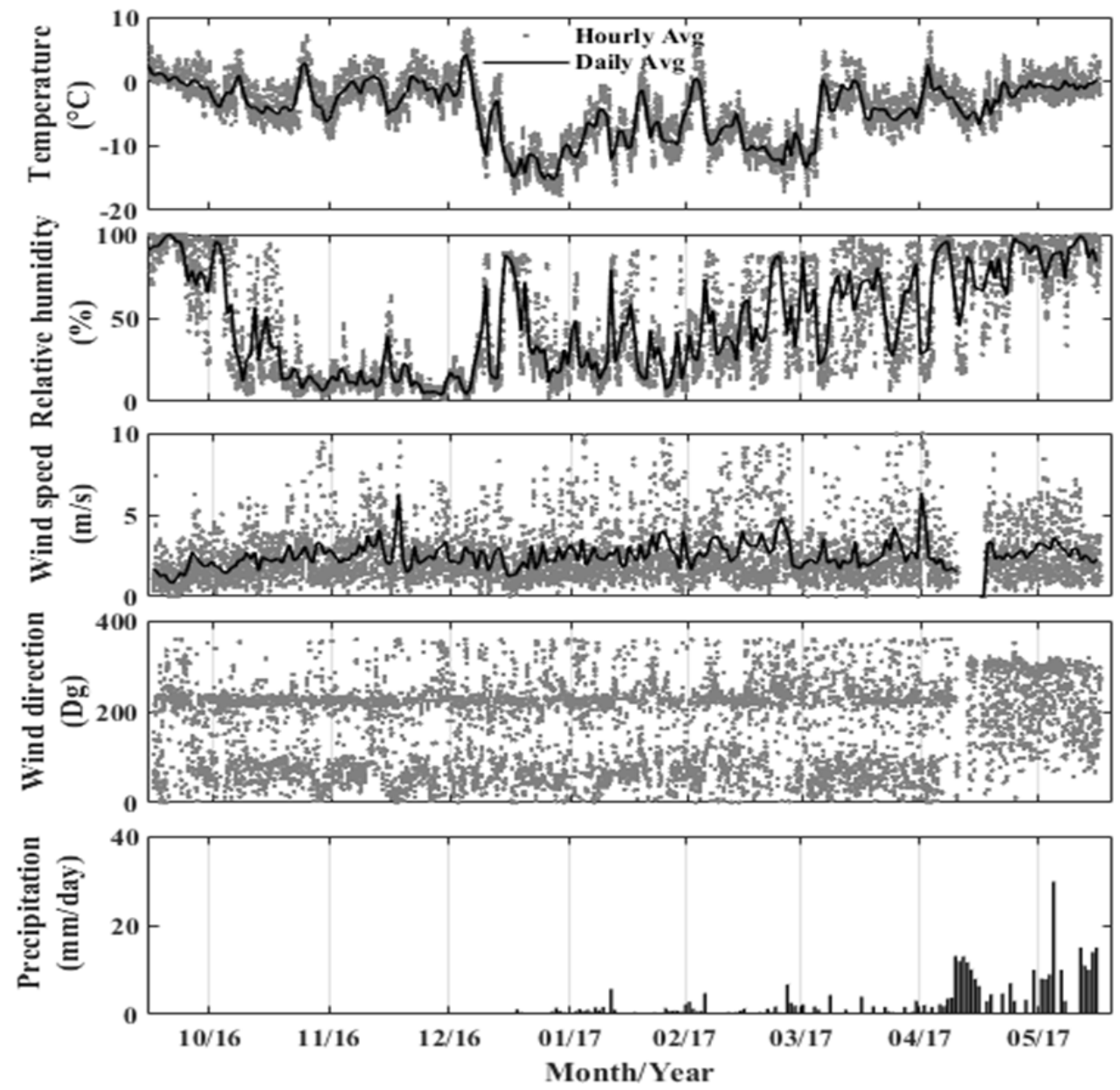

Fig. 2. Hourly and daily variation in temperature, relative humidity, wind speed, wind direction and daily total precipitation. 
present measurements were performed over a high-altitude site (4900 masl) in Nepal. At such a high-altitude location with a complex topography, there is a strong need for the use of fine resolution data. Hence, a $3-\mathrm{km}$ data product was deemed fit for capturing the intricate details over a smaller region. Amongst other data products, at the time of analysis, the MODIS deep-blue algorithm was only available at a $10-\mathrm{km}$ resolution. Hence, we had to use the MODIS 3-km dark-target data product which is globally used and well validated across different regions of the world (Nichol and Bilal, 2016; Gupta et al., 2018; Kumar et al., 2018). There were other data products but those were not suitable to capture the rapidly changing topographical features in this region. Hence, the $3-\mathrm{km}$ dark-target product was used in the present study without applying any corrections. The daily water vapour $\left(1^{\circ} \times 1^{\circ}\right)$ and total columnar ozone $\left(0.25^{\circ}\right.$ $\times 0.25^{\circ}$ ) data over the Yala Glacier region were obtained from the MODIS on board Aqua, and the Ozone Monitoring Instrument (OMI) respectively (Ramachandran and Kedia, 2010). The surface reflectance values were obtained from the MODIS Aqua Level 3 8-day Global SIN Grid product (MYD09A1). These satellite data sets were downloaded from October 2016 to May 2017 for studying the optical properties and subsequently to simulate radiative forcing. Similarly, the aerosol vertical distribution was derived from the Cloud Aerosol Lidar (Light Detection and Ranging) and Infrared Pathfinder Satellite Observation (CALIPSO) Version 3.3 satellite, which has a spatial resolution of $5 \mathrm{~km}$ and Level 2 data set (Dumka et al., 2016). The CALIPSO extinction profiles were downloaded during the study period to understand the distribution of aerosols at an altitude above 4900 masl.

\section{Optical Properties of Aerosols and Clouds (OPAC) Simulation}

The OPAC model was used in the present study to simulate the aerosol optical properties (i.e., SSA and AP) near the Yala Glacier region. As an input to the OPAC model, parameters such as aerosol type, height profile, wavelengths, relative humidity and optical properties needed to be defined. The model allows us to define the aerosol mixture in the absence of chemical composition measurements (Vinoj et al., 2004; Satheesh et al., 2008; Pathak et al., 2010). Thus, in the present case, we used the continental average aerosol type based on soot number concentration. The soot number concentration was calculated using in situ BC mass concentration values and aerosol mass per cubic metre of air $\left(\mathrm{M}^{*}\right)$ following the methodology suggested by Hess et al. (1998). The OPAC model permits the use of RH for 8 different values $(0 \%, 50 \%, 70 \%, 80 \%, 90 \%, 95 \%, 98 \%$, and $99 \%$ ). In the present study, we used the daily mean RH values obtained from the in situ measurements. The height profile of the continental average aerosol type was selected in the OPAC model as defined by Hess et al. (1998) where an assumption was made for constant mixing of air and aerosols in the homogeneous atmospheric layer. Keeping the $\mathrm{BC}$ number concentration constant, the aerosol components (i.e., water-soluble, water-insoluble and mineral transport aerosol concentrations) were varied until the OPAC-derived AOD and AE were consistent with the MODIS retrievals (Babu et al., 2002; Pant et al., 2006; Kedia et al., 2010; Kaskaoutis et al., 2013) (Table 1). It can be observed in Table 1 that the seasonally averaged AOD, the AE used from MODIS and AOD, and the AE simulated from OPAC were almost similar with an approximate error of \pm $5 \%$. Furthermore, as the AE values simulated from OPAC matched well with the AE values retrieved from MODIS, that in itself suggested that all wavelengths of the AOD also matched well. The reason being that a regression between the AOD spectra and its respective wavelengths $(\mu \mathrm{m})$ on a $\log -\log$ scale would produce AE. Hence, the suggestion is that the OPAC-derived results were within the acceptable limits of error and could be used robustly for further analysis. The MODIS-derived AOD has been used earlier to validate the OPAC-derived AOD to determine the robustness of the results (Raju et al., 2016).

\section{Shortwave Aerosol Radiative Forcing Calculation}

The ARF was estimated in the shortwave region $(0.25$ $4 \mu \mathrm{m}$ ) using the Santa Barbara Discrete Ordinate Radiative Transfer Atmospheric Radiative Transfer (SBDART) model. It is based on the discrete ordinate approach developed by the University of California, Santa Barbara. The discrete ordinate method considers the transfer of monochromatic, unpolarised radiation in a scattering, absorbing and emitting plane-parallel medium, with a specified bidirectional reflectivity at the lower boundary (Stamnes et al., 2000). SBDART is capable of computing plane-parallel radiative transfer under both clear and cloudy sky conditions within the earth's top of the atmosphere (TOA) and surface (SURF) (Ricchiazzi et al., 1998; Stamnes et al., 2000). In the present case, the model was run for clear sky conditions. Outputs from the OPAC model (SSA and AP), the satellite-derived AOD, surface albedo, columnar water vapour and total columnar ozone were used as inputs for SBDART. The ARF computations were performed with and without aerosols at hourly intervals. The atmospheric forcing was then calculated by subtracting the radiative flux derived with

Table 1. Seasonal mean aerosol optical properties derived from MODIS and OPAC, and seasonal atmospheric forcing (ATM) and heating rate (HR) near Yala Glacier during the study period.

\begin{tabular}{|c|c|c|c|c|c|c|c|c|}
\hline \multirow[b]{2}{*}{ Seasons } & \multicolumn{2}{|l|}{ MODIS } & \multicolumn{4}{|l|}{ OPAC } & \multirow{2}{*}{$\begin{array}{l}\mathrm{F}_{\text {ATM }} \\
\mathrm{W} \mathrm{m}^{-2}\end{array}$} & \multirow{2}{*}{$\begin{array}{l}\mathrm{HR} \\
\mathrm{K} \text { day }^{-}\end{array}$} \\
\hline & $\begin{array}{l}\text { AOD } \\
550 \mathrm{~nm}\end{array}$ & $\begin{array}{l}\mathrm{AE} \\
\alpha\end{array}$ & $\begin{array}{l}\text { AOD } \\
550 \mathrm{~nm}\end{array}$ & $\begin{array}{l}\mathrm{AE} \\
\alpha\end{array}$ & $\begin{array}{l}\text { SSA } \\
550 \mathrm{~nm}\end{array}$ & $\begin{array}{l}\text { AP } \\
550 \mathrm{~nm}\end{array}$ & & \\
\hline Post-monsoon & 0.045 & 1.13 & 0.044 & 1.18 & 0.910 & 0.677 & 2.6 & 0.244 \\
\hline Winter & 0.040 & 1.15 & 0.042 & 1.19 & 0.905 & 0.670 & 3.8 & 0.186 \\
\hline Pre-monsoon & 0.058 & 1.12 & 0.055 & 1.17 & 0.939 & 0.710 & 4.9 & 0.375 \\
\hline
\end{tabular}


aerosols from the radiative flux without aerosols (Moorthy et al., 2005; Kedia et al., 2010; Nair et al., 2013). The ARF at the TOA and SURF is defined as the change in the net flux (down-up) (Haywood et al., 1999; Ramaswamy et al., 2001). The clear sky ARF at TOA and SURF were computed by using the following relation:

$$
(\Delta \mathrm{F}) \mathrm{TOA}, \mathrm{S}=(\mathrm{FNA}) \mathrm{TOA}, \mathrm{S}-(\mathrm{FA}) \mathrm{TOA}, \mathrm{S}
$$

where $F_{\mathrm{A}}$ and $\mathrm{F}_{\mathrm{NA}}$ are the net fluxes with and without aerosols respectively. The difference between the radiative forcing at the TOA and SURF is expressed as atmosphere forcing (ATM).

$\Delta \mathrm{FA}=(\Delta \mathrm{F}) \mathrm{TOA}-(\Delta \mathrm{F}) \mathrm{S}$

$\Delta \mathrm{F}_{\mathrm{A}}$ represents the amount of energy trapped due to the presence of aerosols within the atmospheric layers (Liou, 2002; Moorthy et al., 2005) where positive forcing indicates the warming potential of the atmosphere. The overall uncertainty in aerosol radiative forcing calculations using SBDART and other input parameters-i.e., in situ BC measurements, OPAC simulations, meteorology and spectral albedo - is estimated to be within 15-20\%, as discussed by earlier studies on the Central Himalayas and the urban areas of South Asia (Pant et al., 2006; Panicker et al., 2010).

\section{Heating Rates}

The atmospheric heating rate due to aerosol forcing is calculated using the following equation:

$\frac{\mathrm{dT}}{\mathrm{dt}}=\frac{\mathrm{g}}{\mathrm{Cp}} \frac{\Delta \mathrm{FA}}{\Delta \mathrm{P}}$

where $\mathrm{dT} / \mathrm{dt}$ is the heating rate $\left(\mathrm{K} \mathrm{day}^{-1}\right), \mathrm{g}$ is the acceleration due to gravity, $\mathrm{Cp}$ is the specific heat capacity of the air, $\triangle \mathrm{FA}$ is the resultant atmospheric forcing, and $\Delta \mathrm{P}$ is the atmospheric pressure (Liou, 2002; Kaskaoutis et al., 2013).

\section{METEOROLOGY}

The seasonal variation in meteorological features over the Himalayas is both influenced by the local mountain wind system and the south-west Indian monsoon system (Ueno et al., 2008; Bonasoni et al., 2010).

The Central Himalayas generally experience four dominant seasons: the pre-monsoon season (March, April, and May), the monsoon season (June, July, August, and September), the post-monsoon season (October and November), and winter (December, January, and February) (Marcq et al., 2010; Shea et al., 2015).

The meteorological conditions at the observation site for post-monsoon, winter and pre-monsoon seasons starting from October 2016 to May 2017 are shown in Fig. 2. The daily and hourly average variations in $\mathrm{RH}(\%)$, air temperature $\left({ }^{\circ} \mathrm{C}\right)$, wind speed $\left(\mathrm{m} \mathrm{s}^{-1}\right)$, daily total precipitation $\left(\mathrm{mm} \mathrm{day}^{-1}\right)$, and hourly average wind direction $\left(^{\circ}\right)$ are presented in separate panels. The mean temperature during the study period was $-4.5 \pm 2.9^{\circ} \mathrm{C}$. The maximum temperature was observed during the post-monsoon season $\left(-1.6 \pm 0.7^{\circ} \mathrm{C}\right)$ followed by pre-monsoon $\left(-4.3 \pm 3.1^{\circ} \mathrm{C}\right)$, and the lowest during the winter season $\left(-6.6 \pm 3.3^{\circ} \mathrm{C}\right)$. Seasonally, the highest $\mathrm{RH}$ was observed during the pre-monsoon season $(68.3 \pm 5.7 \%)$ followed by post-monsoon $(42.2 \pm 38.1 \%)$, and the lowest during the winter season $(29.1 \pm 3 \%)$. The higher RH in the pre-monsoon season was a result of convection over the IGPs. The total precipitation was observed to be the highest during the pre-monsoon season $(301.8 \pm 72.7 \mathrm{~mm})$ and the lowest in winter $(39.7 \pm 11.5 \mathrm{~mm})$. The mean wind speed during the study period was observed to be $2.5 \pm 0.2 \mathrm{~m} \mathrm{~s}^{-1}$ with minimal variation across the different seasons.

\section{RESULTS AND DISCUSSION}

\section{Temporal BC Variation}

The monthly variation in $\mathrm{BC}$ mass concentration during October 2016 to May 2017 is shown as a box-and-whisker plot in Fig. 3. The asterisk symbol (*) in the plot displays the mean, while median, and $25^{\text {th }}$ and $75^{\text {th }}$ percentiles of $\mathrm{BC}$ is represented by the central line, lower and upper boundary of the box in each month. While the upper and lower whiskers indicate the maximum and minimum values, the plus sign $(+)$ indicates the outliers. The monthly mean values indicate that the $\mathrm{BC}$ mass concentration in the atmosphere was the highest during April (1123.2 \pm $\left.1088.8 \mathrm{ng} \mathrm{m}^{-3}\right)$ and the lowest during November $(172.7 \pm$ $95.2 \mathrm{ng} \mathrm{m}^{-3}$ ). A clear seasonal variation in the $\mathrm{BC}$ mass concentration was observed, with the highest in the premonsoon season $\left(707.9 \pm 541.8 \mathrm{ng} \mathrm{m}^{-3}\right)$ and the lowest in the post-monsoon season $\left(243.7 \pm 132.8 \mathrm{ng} \mathrm{m}^{-3}\right)$. The mean $\mathrm{BC}$ mass concentration at the observation site over the 8month period $\left(481.5 \pm 273.7 \mathrm{ng} \mathrm{m}^{-3}\right)$ was comparable to the measurements over Hanle and Meerak in India (Babu et al., 2011; Ningombam et al., 2014), NCO-P in Nepal (Marinoni et al., 2013), and QOMS in China (Cong et al., 2015). The pre-monsoon high observed in the present study was also comparable to the findings of other studies conducted at different high-altitude locations in the Himalayas (Carrico et al., 2003; Marinoni et al., 2010; Babu et al., 2011; Srivastava et al., 2012).

The BC mass concentration starts building up through the winter and reaches its peak during the pre-monsoon season. The high concentration during the pre-monsoon season can be attributed to frequent biomass-burning events in the Indo-Gangetic Plains (IGP) during this season, and the uplifting of pollutants from the adjoining IGP to highelevation regions through convection processes which is due to the high-temperature conditions in the plains (Babu et al., 2011). Apart from that, the long-range transport of aerosols could also play a vital role during this season (Chatterjee et al., 2012; Kumar et al., 2018). Especially during the pre-monsoon season, the Trans-Himalayan valleys act as a channel for transport of pollutants from the IGP to the Himalayas and other high-elevation regions (Dhungel et al., 2018). Similar behaviour was also observed 


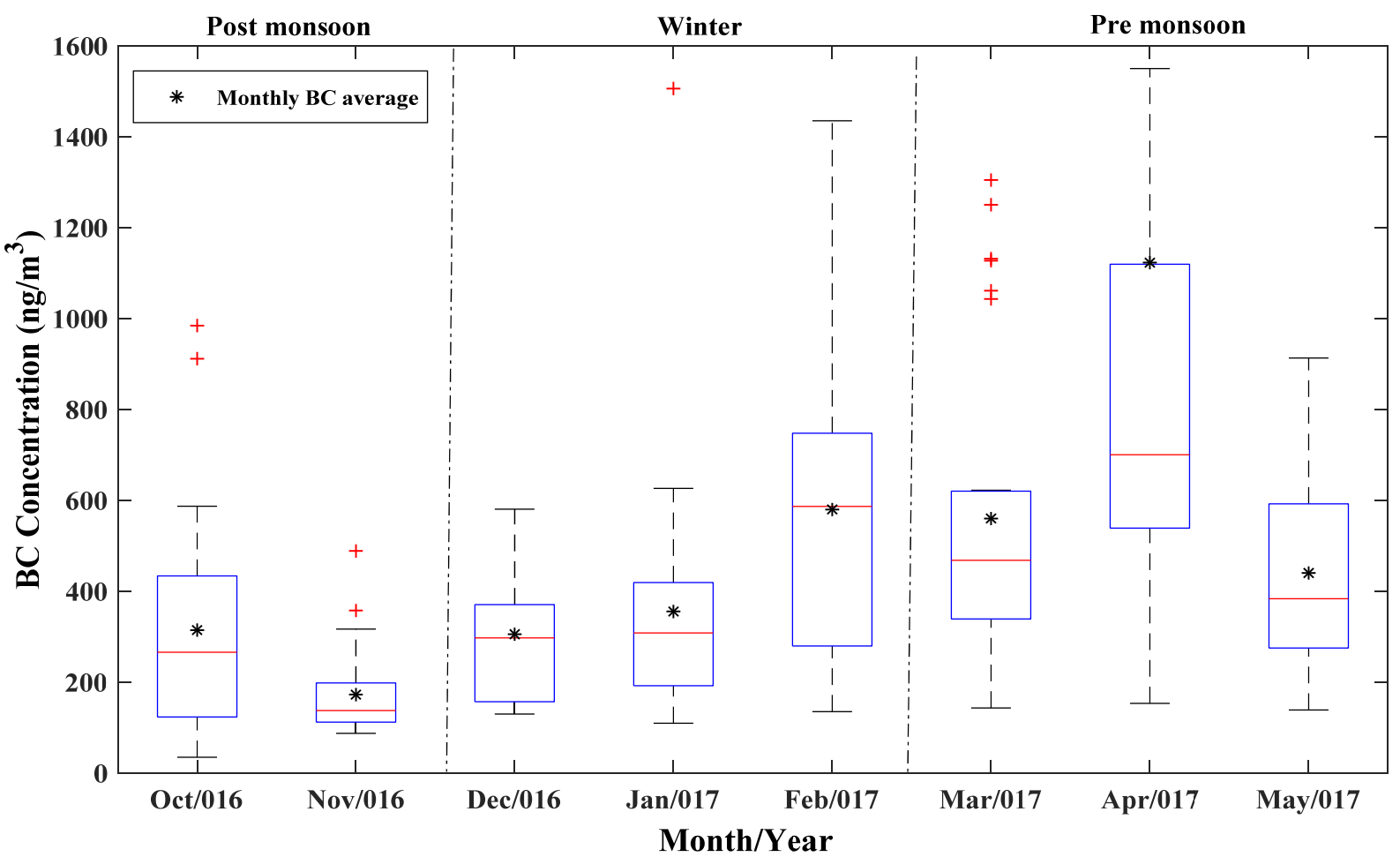

Fig. 3. The monthly box-and-whisker plots for BC near Yala Glacier region, Nepal, during October 2016-May 2017. The asterisk symbol $(*)$ represents mean concentration while the red line represents median. The bottom and top edges of the box indicate the $25^{\text {th }}$ and $75^{\text {th }}$ percentiles. The whiskers represent extreme data points and plus sign $(+)$ is considered as outliers.

at the NCO-P site by Bonasoni et al. (2010). A frequency distribution plot for the daily average $\mathrm{BC}$ mass concentration values for the entire duration of this study is shown in Fig. S2. It indicates that the daily average BC values depict a distinct seasonal variability, with the majority of the values remaining within the 250 and $500 \mathrm{ng} \mathrm{m}^{-3}$ frequency bin. For only $7 \%$ of the days, the daily average BC mass concentration value was observed to exceed $1000 \mathrm{ng} \mathrm{m}^{-3}$; this was primarily in the pre-monsoon season. This indicates the presence of transported aerosols. The post-monsoon season's low concentration is mainly due to the fact that this is the period when precipitation decreases, resulting in an almost clean atmosphere.

\section{Diurnal Variations of Black Carbon Aerosols in Different Seasons}

The mean seasonal diurnal variation in $\mathrm{BC}$ mass concentrations is shown in Fig. 4 (left panel). A distinct diurnal cycle was observed at the study site with gradual increase in concentration soon after sunrise (i.e., 06:00 local time $[\mathrm{LT}]$ ), reaching maximum values during the late afternoons followed by lowest concentrations during the nighttime. Such diurnal profiles have also been observed at other high altitude locations in different parts of the world: Hanle, India (Babu et al., 2011); NCO-P, Nepal (Marinoni et al., 2010); QOMS, China (Chen et al., 2018); and the European Alps (Baltensperger et al., 1997). This diurnal variation was pronounced in the pre-monsoon season gradually decreasing by the winters and not distinct in the post-monsoon season. It is also interesting to note here that wind direction also follows a similar diurnal pattern exhibited by BC (Fig. 4, right panel), thus indicating the strong influence of local meteorology including valley wind flow and planetary boundary layer (PBL) dynamics affecting the diurnal pattern at the study site. The maximum BC concentrations were observed between 12:00 and 18:00 LT during all the seasons. This variation matched well with the PBL changes in the low-lying regions (plains and valleys; Fig. S3), where after sunrise when the boundary layer expands due to heating of the land mass, pollutants along with water vapour find a way to escape from the plains through the valleys and reach up into the high altitudes mixing with the free tropospheric air. Stull et al. (1999) also emphasized that during night-time, shallow nocturnal boundary layer act as a cap that restricts the dispersion and mixing of pollutants. After sunrise, heating of the land surface weaken the residual boundary layer and hence disperse the pollutants by convective processes to higher altitudes that have been documented well in the Himalayan region (Marinoni et al., 2013; Dhungel et al., 2018). In order to analyse the effect of PBL height, the same was extracted within the Langtang region $\left(28.21^{\circ} \mathrm{N}, 85.61^{\circ} \mathrm{E}\right)$ using ERA5 data product $\left(5^{\text {th }}\right.$-generation European Centre for Medium-Range Weather Forecasts [ECMWF] reanalysis climate and weather data) during the study period (Fig. 4, middle panel). The reanalysis data was extracted at a horizontal resolution of $0.25^{\circ} \times 0.25^{\circ}$ and has been used widely (von Engeln and Teixeira, 2013; Hoffmann et al., 2019). Details of the data determining its robustness for use can be found in von Engeln and Teixeira (2013). The diurnal 

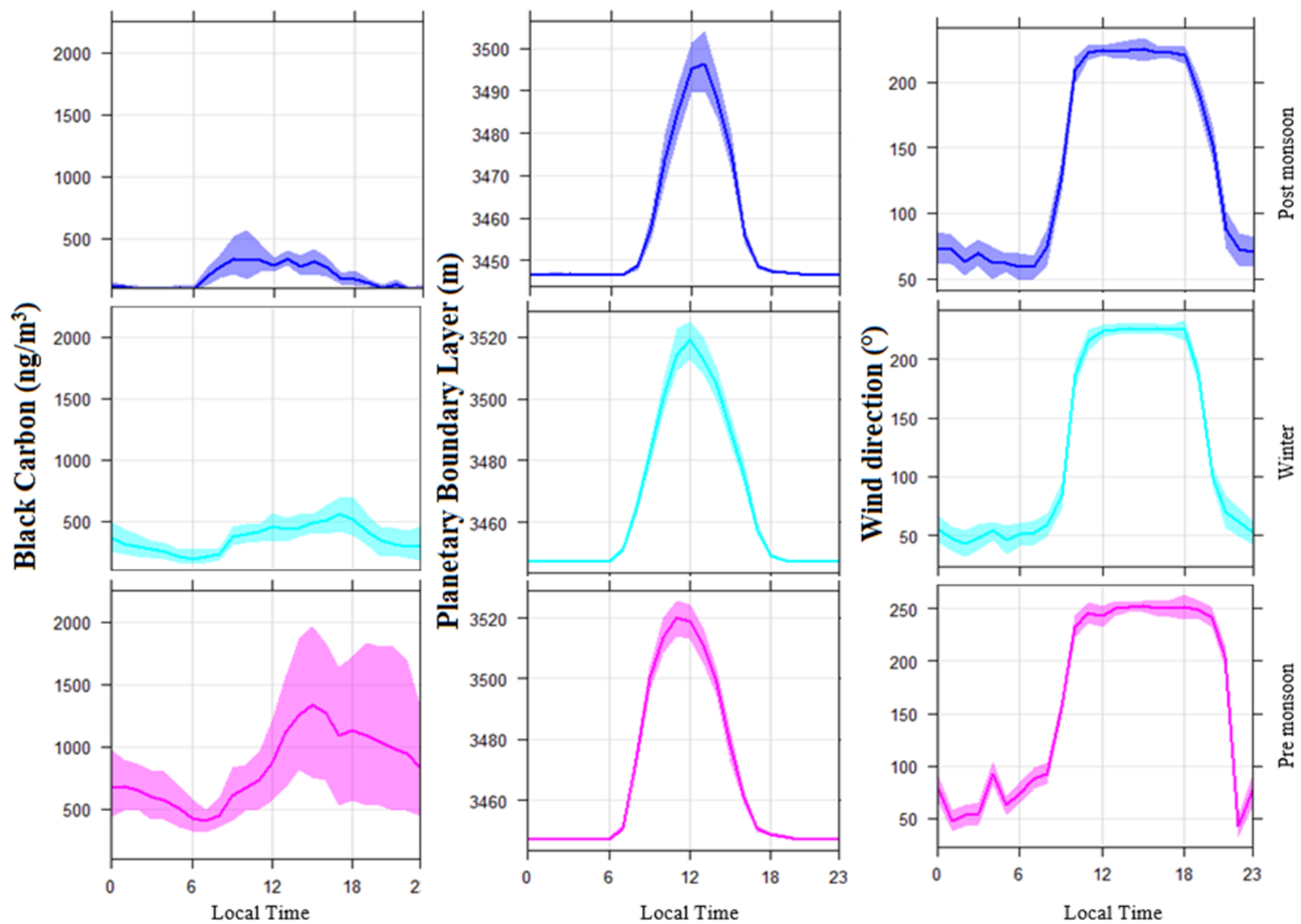

Fig. 4. Seasonal diurnal variation of black carbon, planetary boundary layer height and wind direction near Yala Glacier, Nepal.

pattern of PBL and wind direction (Fig. 4) are in agreement with the fact that during the daytime in the adjacent valleys and plains, when the PBL expands (Fig. S3), it gives a chance for the pollutants to escape to higher altitudes. Further, the south-west wind direction during the daytime very well coincides with the valley wind flow bringing in $\mathrm{BC}$ towards the pollutant site and increasing its concentration.

\section{Local and Regional Source Assessment}

\section{Impact of Local Wind Speed and Direction on BC Mass} Concentration

Wind speed and direction are important factors that influence the atmospheric BC mass concentration. The seasonal wind rose plots (Fig. 5(a)) shown here indicate that the higher frequency of winds predominantly arrived from the SW direction followed by the NE sector, thus indicating a bimodal pattern. Shea et al. (2015) have also pointed out that the wind system at the Yala base camp (i.e., the study site) follow a bimodal distribution pattern, with dominant up-valley (SW) and down-glacier (NE) winds. A similar wind flow pattern has also been observed by earlier studies in this region, at Khumbu, Nepal (Bollasina et al., 2002); Langtang, Nepal (Carrico et al., 2003); and NCO-P, Nepal (Bonasoni et al., 2010b). Now, in order to understand the potential sources and distribution of the $\mathrm{BC}$ mass concentration with respect to wind direction and speed, the concentration bivariate probability function (CBPF) analysis was used. The wind rose plots demonstrate that the predominant wind direction was south-westerly. Now, combining wind speed, wind direction and the $\mathrm{BC}$ mass concentration, the CBPF plots (Fig. 5(b)) indicate that a higher $\mathrm{BC}$ mass concentration was associated with the dominant wind direction at the study site. Primarily during the pre-monsoon season, the up-valley south-west winds bring in different pollutants from the low-lying plain regions (Nepal and the IGP). Previous studies also indicated the role of mountain topography and valleys in transporting the pollutants from the plains to the higher altitudes (Whiteman, 2000), thus indicating the strong role of the transported $\mathrm{BC}$ due to higher convection in the low-lying plain regions in the pre-monsoon season. During the postmonsoon season, the atmosphere is relatively cleaner, resulting in lower $\mathrm{BC}$ mass concentration, while during winter season, the transport of $\mathrm{BC}$ does not seem likely due to temperature inversion and subsidence in the low-lying plain region.

CWT Analysis to Determine Long-distance Sources of BC

While wind rose and CBPF plots indicate the dominant directions from which the higher concentration of $\mathrm{BC}$ was arriving, they do not provide appropriate information about the distant sources. Hence, in order to understand the 


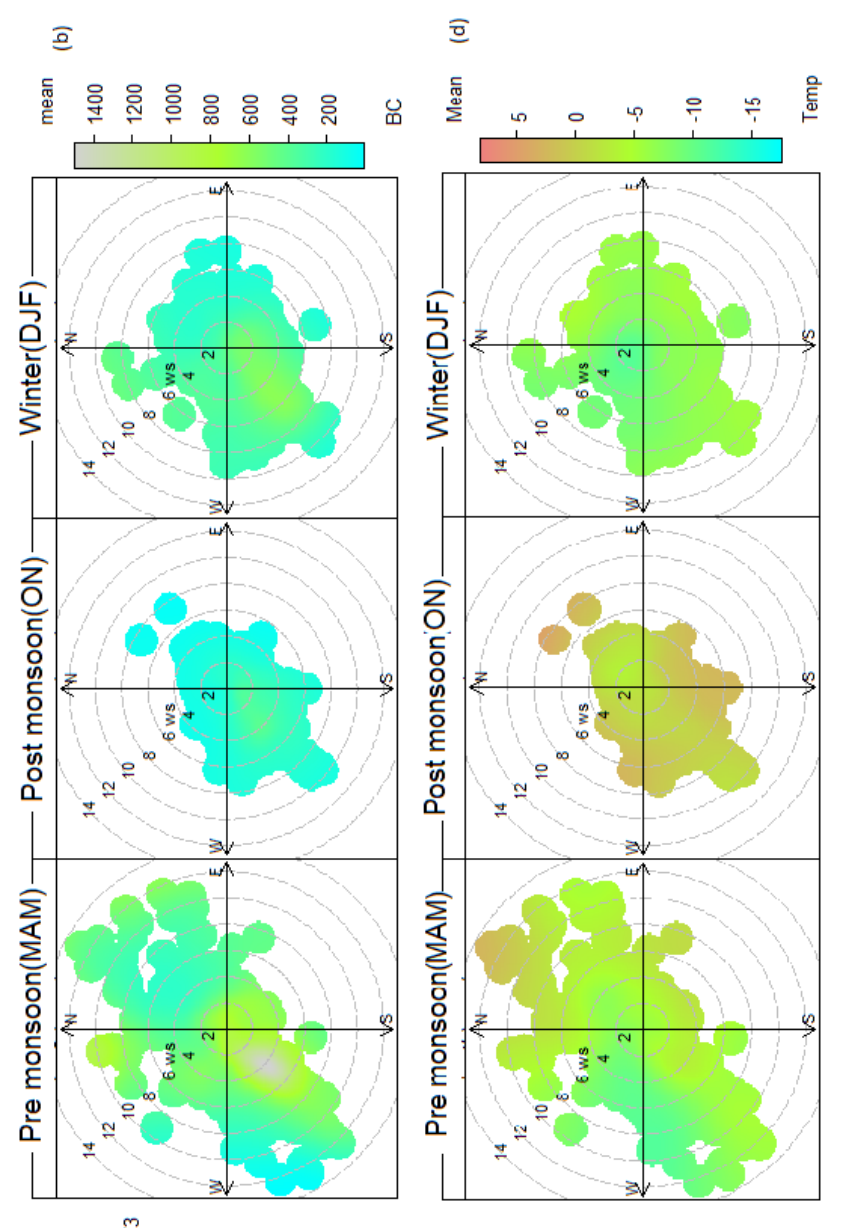

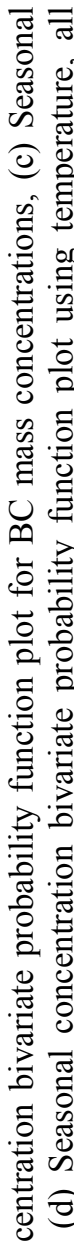
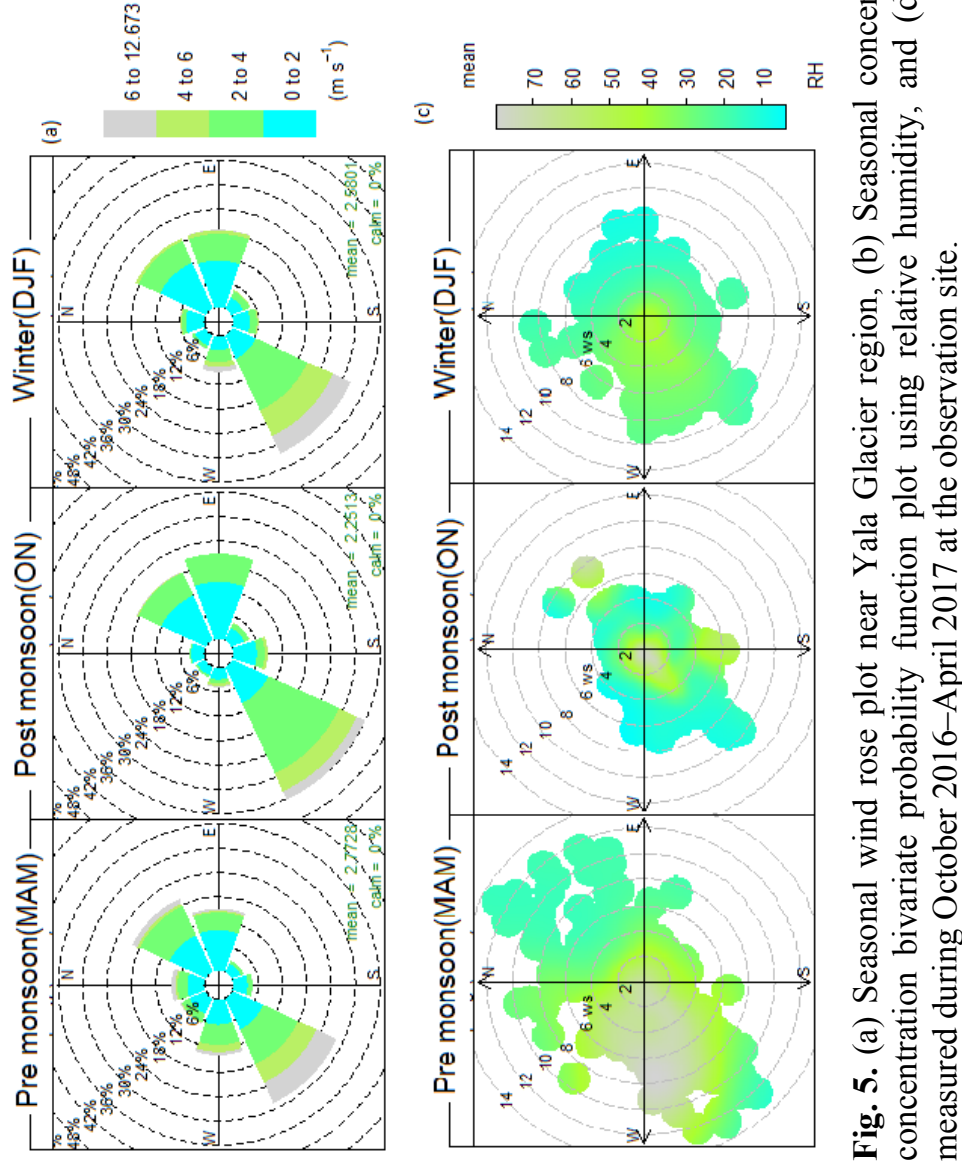
potential source region of the transported BC (from distant areas) to the receptor site (near Yala Glacier), a concentrationweighted trajectory (CWT) analysis was performed. For this analysis, 5-day air mass back trajectories were generated at 00:00 (UTC) and at an altitude of $100 \mathrm{~m}$ above ground level using Hybrid Single Particle Lagrangian Integrated Trajectory (HYSPLIT) model for the entire study period. Such an analysis has been widely used by researchers (Vinoj et al., 2010; Sen et al., 2017; Mahapatra et al., 2018) in order to understand the source location of the aerosols transported to the receptor site. This analysis has been performed using TrajStat 1.2.2.6, a GIS based software as described in Wang et al. (2009). CWT analysis for an individual grid cell $(i, j)$ is an indicator of the source strength of the particular grid cell with respect to the receptor site under study which is given by the following equation:

$$
C W T_{i j}=\frac{\sum_{l=1}^{L} C_{l} \tau_{i j l}}{\sum_{l=1}^{L} \tau_{i j l}}
$$

where $C_{i}$ is the concentration of the grid cell with back trajectory index $l . L$ is the total number of trajectories and $\tau_{i j l}$ is the time spent in $i, j^{\text {th }}$ cell by trajectory $l$ (in other words the residence time of a particular trajectory in each grid cell). A higher value of $C_{i}$ indicates that the air mass travelling over the $i, j^{\text {th }}$ cell would be associated with a higher pollutant concentration at the receptor site. Fig. 6 displays the CWT maps for BC on a seasonal basis during 2016-2017. During the winter season, the major source location of $\mathrm{BC}$ is in the west to north-west sectors comprising parts of different high-altitude locations starting from the Karakoram region, the Tibetan Plateau, lowland regions of Nepal and parts of the IGP. However, due to non-conducive meteorological conditions prevailing in the lowland region, the long-range transport of $\mathrm{BC}$ is not expected to strongly impact the $\mathrm{BC}$ build-up at the receptor site in winter. In the pre-monsoon season, the potential source regions of $\mathrm{BC}$ were primarily local in nature and from some parts of Nepal, Bangladesh, the IGP, and the far north-west regions of the study site. Thus, due to a combination of stronger convective activity during the pre-monsoon season and potential local sources of emissions, a higher concentration of $\mathrm{BC}$ was observed at the receptor site. As only $0-2 \%$ of the trajectories seem to cross the Arabian Sea region in the pre-monsoon season, these can be considered as outliers. Such outliers can also be observed in previous studies performed in the nearby Himalayan region (Marioni et al., 2010; Babu et al., 2011). The post-monsoon season indicates inflow of air from the near and far north-west sectors, which arrive through the nearby high-altitude regions. Simultaneously, this period also coincides with the monsoon decaying phase at the source locations and the observation site. Thus, the long-range transport of $\mathrm{BC}$ in this season is not expected to contribute significantly to the BC build-up at the receptor site.

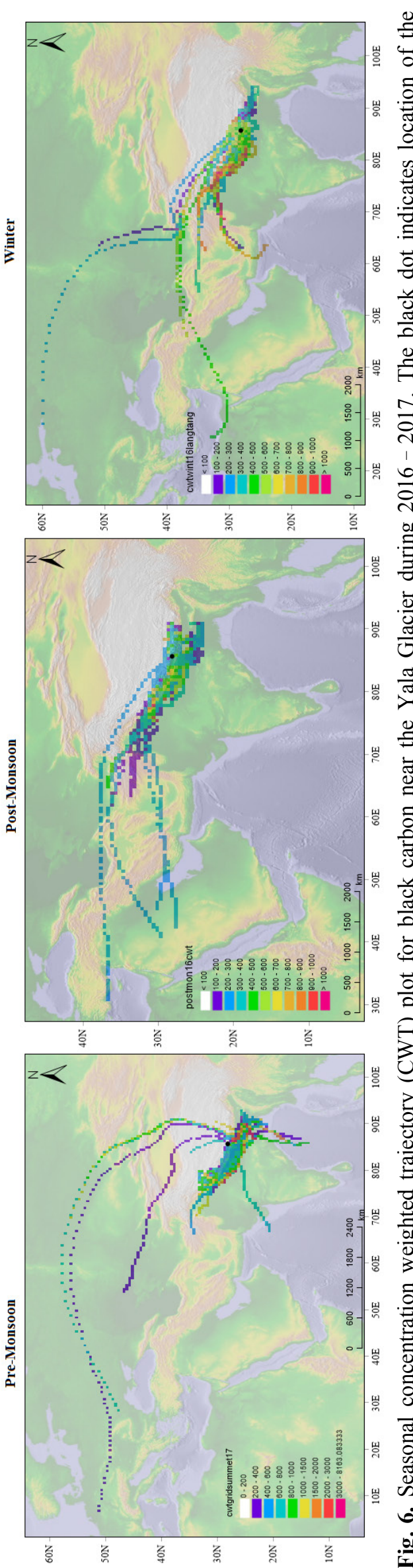

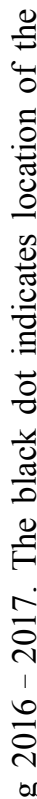




\section{Effect of Meteorological Parameters}

Mountain meteorology, in itself, is a complex feature due to the surrounding topography and high altitudes. In the present study, we made an attempt to understand the impact of relative humidity and rainfall on $\mathrm{BC}$ variability using scatter plots. Figs. 7(a) and 7(b) depicts the correlation of $\mathrm{BC}$ with relative humidity. The scatter plots were created (after removal of precipitation events) for two conditions: (i) relation of $\mathrm{RH}<50 \%$ with $\mathrm{BC}$ and (ii) relation of $\mathrm{RH}>$ $50 \%$ with BC. From the graphs, it is visible that during lower relative humidity $(<30 \%)$, the $\mathrm{BC}$ mass concentration is observed to be low. Only during moderate relative humidity, the $\mathrm{BC}$ mass concentration is observed to be high. A similar phenomena of anomalous RH behaviour has also been observed at a high-altitude urban location in the nearby region (Zalakeviciute et al., 2018).

During the winter season, as cold air moves from the upper atmosphere towards the lowlands, temperature inversion and strong subsidence effects have been observed at a height of $1-3 \mathrm{~km}$ from the surface, as a result of which pollutants and water vapour in the adjoining lowland regions, located south of the study site (Rupakheti et al., 2017; Bikkina et al., 2019) get stuck close to the surface, not getting a chance to be transported high up into the valleys reaching the mountain top (Dhungel et al., 2018), thus increasing the surface pollution in the plains and enhancing phenomena like winter fog. However, as the observation site is situated at an altitude of 4900 masl, it receives the free tropospheric cold air that does not contain pollutants and makes the site much drier in the winter season. Hence, primarily during the winter season, along with lower relative humidity, the concentration of pollutants is expected to be lower, which purely represents the free tropospheric air mass at the observation site.

But during the pre-monsoon season, as temperature accelerates drastically in the plains, hot air (along with the pollutants and moisture) tends to rise up and condense due to lower temperatures high in the atmosphere aiding in cloud formation due to the convective processes. While in the process of lifting of pollutants, they find their way through mountain valleys and reach the mountain tops. Hence, during the pre-monsoon season with a moderate level of relative humidity, the transport of air pollutants from the plain regions is expected to increase the $\mathrm{BC}$ mass concentration at the observation site. The same can be well substantiated by the CBPF plots for BC, RH, and temperature (Figs. 5(b)-5(d)). It shows that the winds are prominently arriving from the $\mathrm{SW}$ region with a higher load of $\mathrm{BC}$ mass concentration and moderate to high $\mathrm{RH}$ and temperature. However, during the post-monsoon seasons, though winds arrive from the south-west region, the pollutant concentrations are lower.

Similarly, at a higher relative humidity ( $>90 \%$ ), the BC mass concentration is again observed to be low, which might be due to the scavenging of $\mathrm{BC}$ aerosols. During higher humidity conditions, the internally mixed $\mathrm{BC}$ aerosols might exhibit a greater hygroscopicity by acting as a cloud condensation nuclei and subsequently get scavenged in the form of cloud droplets. Similar features have also been observed at other high alpine sites (Cozic et al., 2007).

The scatter plot of $\mathrm{BC}$ with rainfall (Fig. 7(c)) indicates a negative slope, which provides insights into the scavenging effect. However, the correlation is not strong, which may be due to the non-inclusion of monsoon period data in the present study.

\section{Aerosol Optical Properties}

Aerosol Optical Depth (AOD)

The most important optical property of aerosols is the AOD, which is directly proportional to the magnitude of the attenuation of direct solar radiation by the scattering and absorption process (Charlson et al., 1992). AOD is a measure of the extinction of the solar beam by the aerosols distributed within an atmospheric column. The monthly mean AOD, along with its standard deviation, is shown in Fig. 8 (top). In the present study, the mean AOD, derived from the MODIS during the study period (October 2016May 2017), was observed to be $0.05 \pm 0.01$ while OPAC derived AOD was found to be $0.047 \pm 0.007$. Such lower values are indicative of a cleaner environment typical of
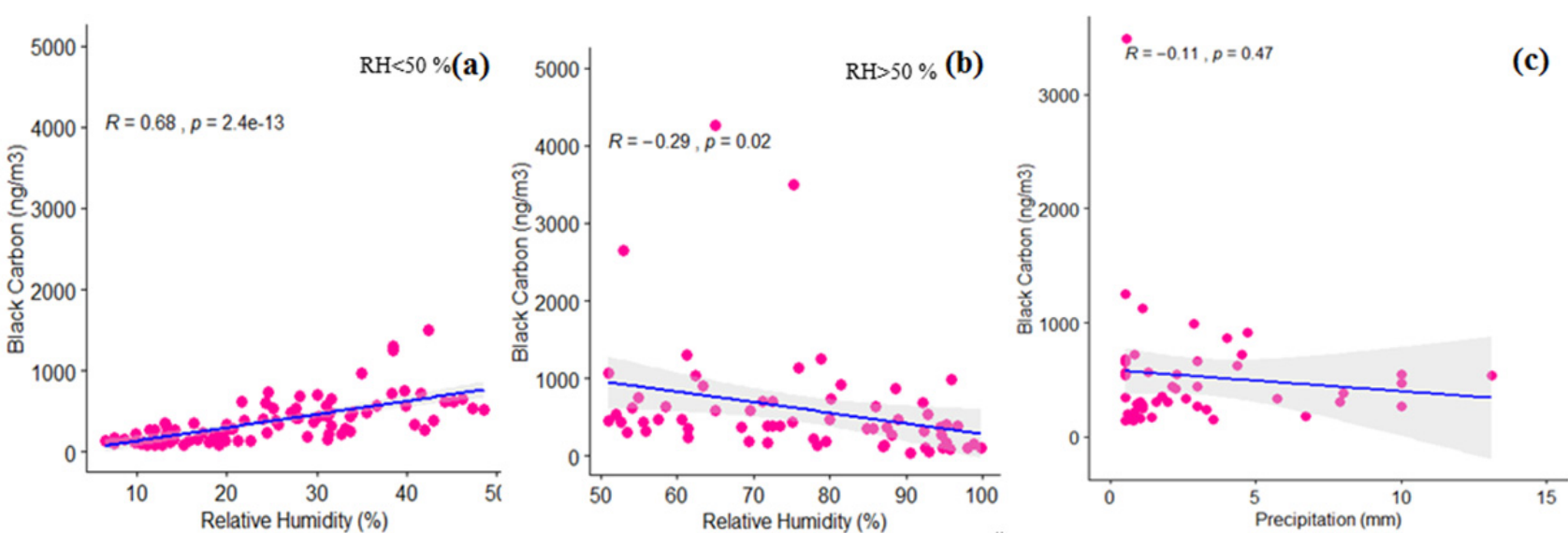

Fig. 7. Scatter plot showing (a) daily average $\mathrm{BC}$ mass concentration and $\mathrm{RH}<50 \%$ after removal of precipitation events, (b) daily average $\mathrm{BC}$ mass concentration and $\mathrm{RH}>50 \%$ after removal of precipitation events, (c) daily average BC mass concentration and rainfall during October 2016-May 2017. 

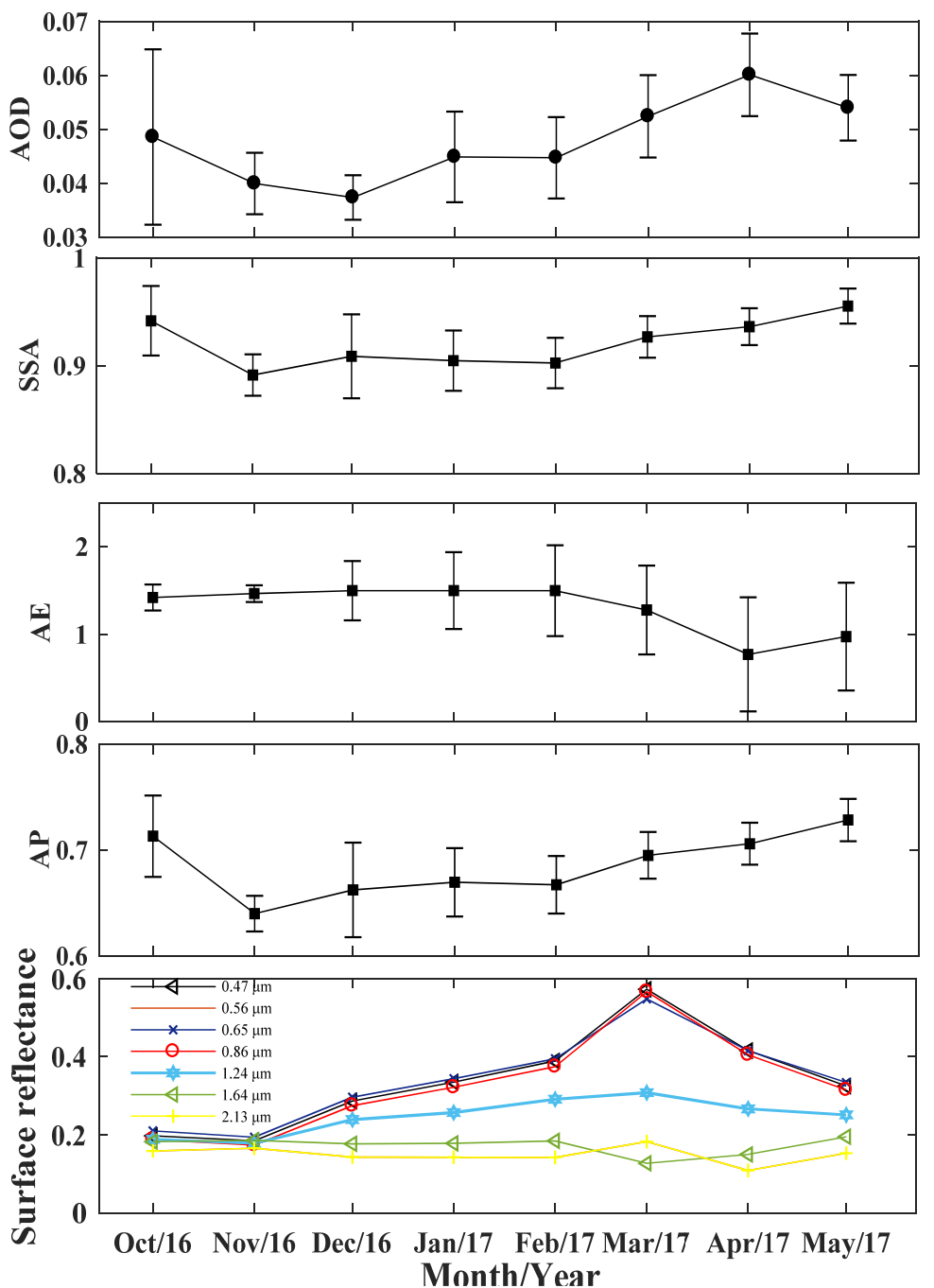

Fig. 8. Monthly mean aerosol optical properties with $\pm 1 \sigma$ (standard deviation) and surface reflectance near Yala Glacier region during October 2016 to May 2017.

high-altitude locations (Pant et al., 2006; Marcq et al., 2010; Ningombam et al., 2014). The spectral AOD decreases with increase in altitude, and vice versa. The findings from NCO-P, Nepal, revealed AOD values in the range of 0.01 \pm 0.00 to $0.10 \pm 0.03$ (Marcq et al., 2010), while those from Hanle (Verma et al., 2010) and Meerak (Ningombam et al., 2014) were observed to be $\sim 0.05$ and 0.06 respectively, indicating a similarity in pollution levels at different highaltitude Himalayan locations. The seasonal variation of AOD indicated a pre-monsoon high (0.06), followed by a post-monsoon low (0.05), and falling to the lowest during winter (0.04). The pre-monsoon high AOD values can again be attributed to frequent biomass-burning events in the lowlands, convective lifting and long-range transport of the aerosols (Carrico et al., 2003). The higher AOD observed from satellite data in the pre-monsoon season is also consistent with in-situ observations of a higher BC mass concentration.

Single Scattering Albedo (SSA)

Whether carbonaceous particles principally warm or cool the atmosphere depends on the aerosol SSA, which is the ratio of the incident radiation that is scattered to the incident radiation that is absorbed. SSA is the ratio of the scattering to the extinction coefficient of aerosols, and is one of the fundamental properties of the aerosol required to determine aerosol radiative forcing (Moorthy et al., 2005; Pant et al., 2006; Chung, 2012). Generally, the SSA value $>0.9$ suggests the dominance of scattering aerosols (Kedia et al., 2010; Chakrabarty et al., 2012). This also indicates that extinction results primarily from scattering (Bond and Bergstrom, 2006). However, SSA value $<0.9$ indicates the absorbing nature of the aerosols which can contribute to the heating of the atmosphere (Ramanathan and Carmichael, 2008; Praveen et al., 2012).

The OPAC-simulated SSA (at $0.55 \mu \mathrm{m}$ ) during the study period was estimated to be in the range of 0.905-0.939. The mean SSA during the study period was $0.92 \pm 0.02$, indicating the scattering nature of the aerosols. The SSA values derived near the observation site is comparable to the SSA values estimated at other high-altitude sites, i.e., 0.89 at NCO-P, Nepal (Marcq et al., 2010), and 0.98 at 
Merak, India (Ningombam et al., 2014). In terms of season, SSA was observed to be higher during pre-monsoon (0.94) followed by post-monsoon (0.90) and winter (0.91).

Despite the higher $\mathrm{BC}$ mass concentration during the pre-monsoon season, a higher SSA value can be explained by the presence of higher moisture content in the atmosphere, thus indicating the overall dominance of scattering aerosols. Aerosols can absorb moisture depending on their chemical composition and the ambient $\mathrm{RH}$, which change their phase and growth (Nessler et al., 2005). As RH increases, the radius of hygroscopic aerosols (i.e., water-soluble, mineral-transporting particle) also increases. The increase in the size of aerosols favour a higher SSA (Hess et al., 1998; Ramachandran and Kedia, 2010; Titos et al., 2014). Hence, a higher RH (60.3\%) recorded at the observation site during the pre-monsoon season might be responsible for enhancing the scattering nature of the aerosols (Carrico et al., 2003; Howell et al., 2006). The lowest SSA value (0.88) was observed in the month of November, which can be attributed to the lower RH (15.2\%) observed in this month.

\section{Angström Exponent (AE)}

The $\mathrm{AE}$ is an indicator of aerosol particle size (Ångström, 1964). The values of AE close to 2 indicate the dominance of fine particles associated with combustion by-products, and values less than 1 indicate large particles like sea salt and dust (Schuster et al., 2006; Dumka et al., 2014). The MODIS-derived AE near the Yala Glacier was observed to be in the range of $1.12-1.18$, with a mean value of $1.13 \pm 0.015$ during the study period. While the seasonal average of the OPAC-derived AE was in the range of 1.17-1.19 (Table 1), the monthly values have been shown in Fig. 8. This indicates the presence of fine-mode aerosols over the study site. Ningombam et al. (2014)'s study from high-altitude locations also found the higher value (i.e., $1.36 \pm 0.18$ ), suggesting the dominance of finemode aerosols over the high-altitude Himalayan locations (Dumka et al., 2014; Ningombam et al., 2014).

\section{Asymmetry Parameter (AP)}

The AP is the first moment of phase function and an important parameter for calculating radiative transfer (Korras-Carraca et al., 2015). Besides AOD, one of the most important optical properties of atmospheric particles, which is used in radiative transfer, climate, and general circulation models, is the AP. The AP describes the angular distribution of the scattered radiation and determines whether the particles scatter radiation preferentially to the front or back (Haywood and Shine, 1995; Kassianov et al., 2007).

The AP can be obtained by using the measured backscatter fraction (Wiscombe and Grams, 1976). Positive values of the AP denote forward scattering, with values increasing with particle size, whereas negative values indicate backward scattering. In our study, the monthly variations in the AP was in the range of 0.64 to 0.77 , indicating the forward scattering of the radiation by atmospheric aerosols. These values were also comparable to that observed by Marcq et al. (2010) in the NCO-P site,
Nepal (0.65-0.78), and Ningombam et al. (2014) in the Merak station, India $(0.68 \pm 0.01)$.

\section{Estimation of ARF and Heating Rate}

Seasonal Radiative Forcing

The seasonal mean radiative forcing is presented in Fig. 9. Positive forcing was observed for TOA and atmosphere (ATM), whereas negative forcing was observed at SURF during all seasons. The mean forcing in TOA, SURF and ATM during the study period was estimated to be $3.4 \mathrm{~W} \mathrm{~m}^{-2}$, $-0.5 \mathrm{~W} \mathrm{~m}^{-2}$ and $3.9 \mathrm{~W} \mathrm{~m}^{-2}$ respectively. In terms of season, ATM was estimated to be maximum during the pre-monsoon season $\left(4.9 \mathrm{~W} \mathrm{~m}^{-2}\right)$, followed by winter $\left(3.8 \mathrm{~W} \mathrm{~m}^{-2}\right)$, and the lowest in the post-monsoon season $\left(2.6 \mathrm{~W} \mathrm{~m}^{-2}\right)$. During the pre-monsoon season, TOA and ATM forcing becomes increasingly positive due to the high concentration of aerosols (indicated by in situ BC and AOD values) and surface albedo, implying a greater atmospheric warming potential in this season. Nair et al. (2013) suggest that BC and dust are major aerosol components in winter and the pre-monsoon season, which can be attributed to high atmospheric forcing. This corroborates our finding of higher ATM forcing in the pre-monsoon season. Moreover, the MODIS-derived surface albedo was observed to be higher during the pre-monsoon season $(0.43)$ in comparison to the post-monsoon season $(0.19)$ and winter $(0.34)$ due to the snow-covered surface of the Yala Glacier region. Hence, a higher albedo in the pre-monsoon season is expected to enhance the radiative forcing. Positive ATM indicates warming of the atmosphere by absorbing aerosols, whereas negative SURF is attributed to aerosol backscattering and the high surface albedo. The SURF remains negative due to the attenuation of solar flux by the aerosols (Patel and Kumar, 2015). A comparative study of other high-altitude sites within the Hindu Kush Himalayan (HKH) regionNCO-P in Nepal, and Hanle and Meerak in India (Table 2)indicates similar atmospheric forcing at most locations.

\section{Atmospheric Forcing on Different Surfaces}

The earth's surface near the Yala Glacier is covered with snow, rocks or grass, depending on the local conditions and seasonal variabilities as described in Section 4. Thus, it is important to understand the variation in atmospheric forcing which might originate due to differences in surfaces. Hence, on a daily basis, we simulated radiative forcing based on different types of surface parameters. In order to do that, values for different surface albedos were given as an input in the SBDART model. The grass (0.3), snow (0.9) and the rock surface (0.2) albedo were taken from Frenzel (1992) and Voogt and Oke (1998). The mean ATM forcing during the study period for rock, grass and snow surfaces was estimated to be $3.7 \mathrm{~W} \mathrm{~m}^{-2}, 4.1 \mathrm{~W} \mathrm{~m}^{-2}$ and $4.3 \mathrm{~W} \mathrm{~m}^{-2}$ respectively (Fig. 10). Lower ATM forcing was observed in the case of rock and grass surfaces, which might be due to lower albedo values for such surfaces. Hence, especially during the pre-monsoon season when the earth's surface is covered by snow near the observation site, atmospheric forcing is observed to be higher (Fig. 10). To summarise, higher surface albedo due to a snow-covered earth surface 


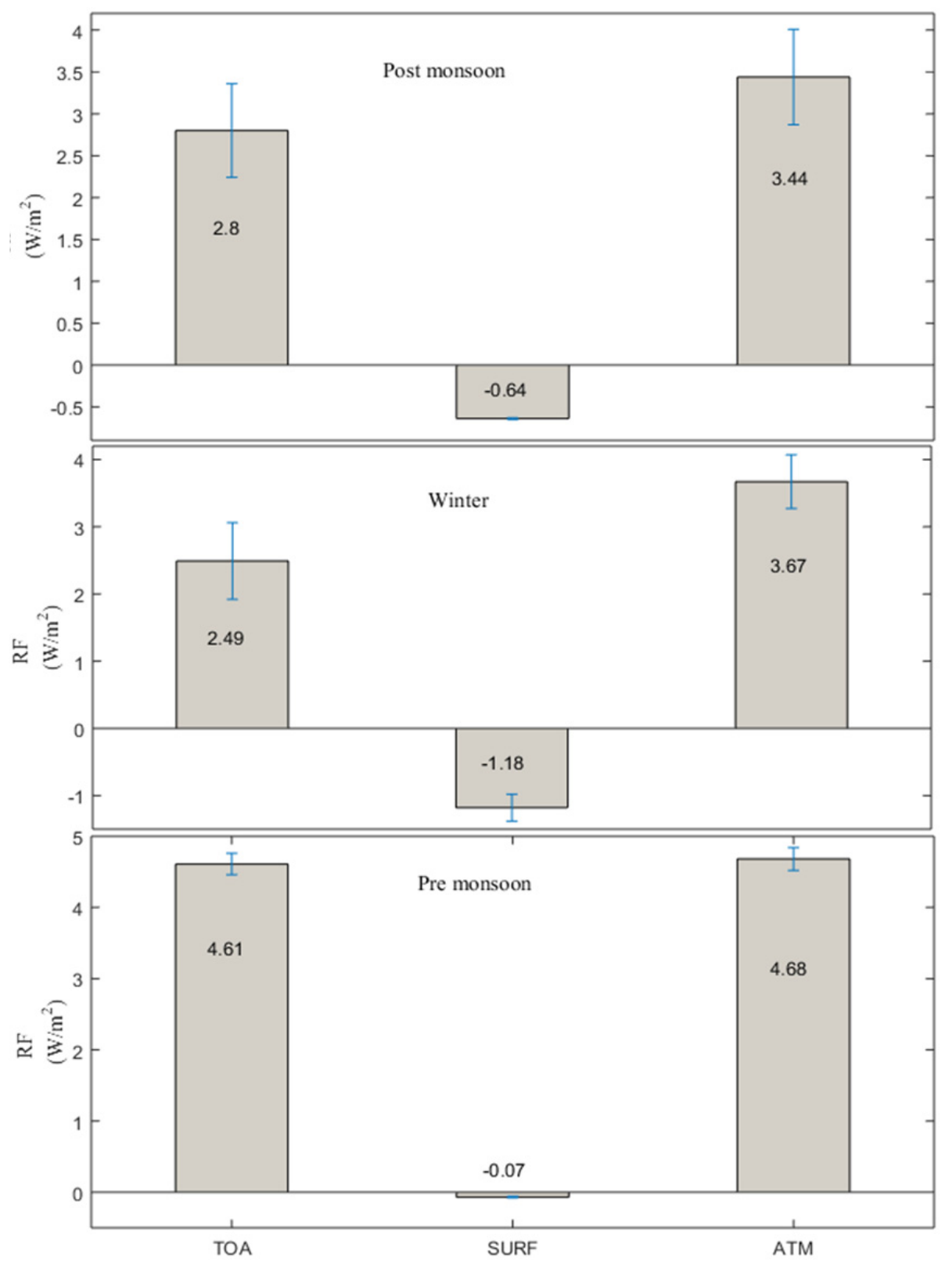

Fig. 9. Seasonal variation in mean TOA, SURF and ATM forcing estimated near Yala Glacier region, Nepal, during the study period.

Table 2. Comparison of ARF at different high-altitude sites within the HKH region.

\begin{tabular}{lllll}
\hline Study sites (masl) & TOA $\left(\mathrm{W} \mathrm{m}^{-2}\right)$ & SURF $\left(\mathrm{W} \mathrm{m}^{-2}\right)$ & ATM $\left(\mathrm{W} \mathrm{m}^{-2}\right)$ & Sources \\
\hline Near Yala Glacier, Nepal (4900) & +3.4 & -0.5 & +3.9 & Present study \\
NCO-P, Nepal (5079) & +2.1 & -1.6 & +3.7 & Marcq et al. $(2010)$ \\
Hanle, India (4500) & +1.7 & -1.5 & +3.2 & Nair et al. $(2013)$ \\
Merak, India (4300) & -0.4 & -6.4 & +2.6 & Ningombam et al. (2014) \\
\hline
\end{tabular}

in the pre-monsoon season and higher concentration of aerosols (indicated by higher $\mathrm{BC}$ mass concentration and AOD values) support the increase in ATM forcing observed in this season.

Vertical Distribution of Aerosols and Heating Rates

The amount of radiation absorbed/scattered by aerosols in different layers of the atmosphere influences radiative forcing and subsequently the heating rates (Liou, 2002; Moorthy et al., 2005; Kedia et al., 2010; Dumka et al., 2016). Aerosol radiative forcing largely depends on the vertical distribution of aerosols, the lack of which can introduce unwanted biases into the study (Forster et al., 2007). Hence, in the present case, we used CALIPSO 


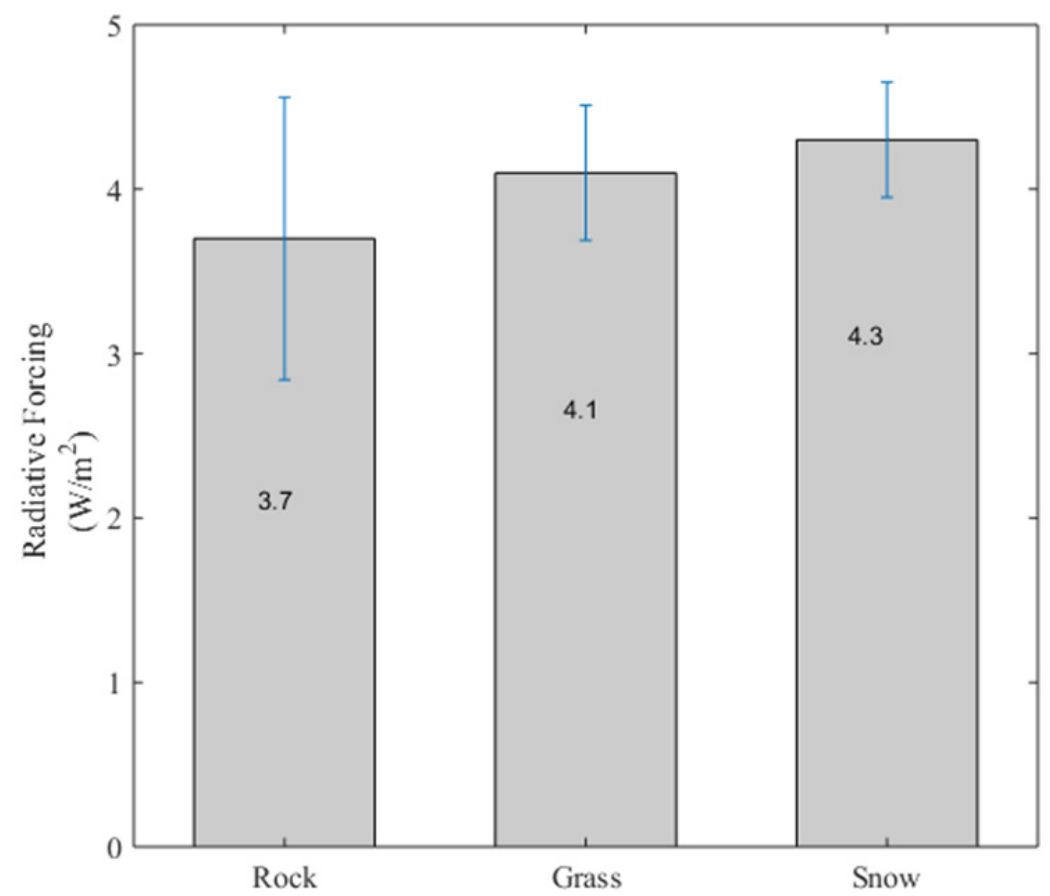

Fig. 10. Estimated radiative forcing over rock, grass and snow surfaces near Yala Glacier region.

extinction profiles to understand the vertical distribution of aerosols and subsequently calculated the heating rates using the SBDART model (Kedia et al., 2010; Praveen et al., 2012; Dumka et al., 2016). Fig. 11 shows the seasonal distribution of aerosol extinction profiles over the Yala Glacier region. As our observation site was situated at an altitude of 4900 masl, we studied the aerosol extinction above the altitude of $4.9 \mathrm{~km}$ only. The seasonal aerosol extinction profiles during winter indicate the presence of aerosol till $\sim 7 \mathrm{~km}$ elevation, but during the pre-monsoon and post-monsoon seasons, aerosols were observed even up to an altitude of $\sim 8 \mathrm{~km}$. Higher aerosol extinction profiles observed during the pre-monsoon season might be attributed to vertical mixing or the long-range transport of aerosols as discussed above (Kovalev and Eichinger, 2004; Dumka et al., 2016). Such processes have been studied in the Himalayan region of Nepal (Dhungel et al., 2018).

Fig. 12 depicts the seasonal heating rate (HR) profiles estimated at a height of $4.9 \mathrm{~km}$ over the study site. The HR was observed to decrease with height, which was also commensurate with the reduction in aerosols as the height increased. During the post-monsoon and pre-monsoon seasons, the HR profile extended up to $8 \mathrm{~km}$, while in winter it was limited to $7 \mathrm{~km}$. The mean HR during the study period was estimated to be $0.268 \pm 0.117 \mathrm{~K} \mathrm{day}^{-1}$. In terms of season, the mean HR was observed to be the highest during the pre-monsoon season $\left(0.375 \pm 0.131 \mathrm{~K} \mathrm{day}^{-1}\right)$, followed by the post-monsoon season $\left(0.244 \pm 0.085 \mathrm{~K} \mathrm{day}^{-1}\right)$, and the lowest during the winter season $\left(0.186 \pm 0.135 \mathrm{~K}_{\text {day }}{ }^{-1}\right)$. The higher HR in the pre-monsoon season over the study site was firmly supported by the higher BC mass concentration and AOD values. The present study findings are comparable with the findings of Marcq et al. (2010) from NCO-P, Nepal, where the heating rate was estimated to be $0.2 \mathrm{~K} \mathrm{day}^{-1}$ over the snow surface. Similarly, the study in Merak, India, also revealed the heating rate to be $0.22 \pm 0.12 \mathrm{~K} \mathrm{day}^{-1}$, indicating the role of aerosols in heating up the atmosphere.

\section{CONCLUSIONS}

The present study estimated the aerosol radiative forcing near Yala Glacier region from October 2016 till May 2017 using in situ BC mass concentrations, satellite data sets, and model simulations. The mean BC mass concentration at the study site was observed to be $481.5 \pm 273.7 \mathrm{ng} \mathrm{m}^{-3}$, with the highest concentration observed in the pre-monsoon season. The diurnal behaviour of the $\mathrm{BC}$ mass concentration was strongly influenced by the boundary layer dynamics and valley wind flow patterns. The dominance of south-westerly winds, indicating a valley inflow path, was responsible for increased $\mathrm{BC}$ concentrations at the observation site during the afternoons. Based on the air masses arriving at the site, the $\mathrm{BC}$ was transported from Karakoram, the Indo-Gangetic Plain, Nepal, and Bangladesh, with the major source regions being Nepal, and Bangladesh, and part of the IGP during the pre-monsoon season. Optical properties of the aerosols indicate higher SSA and AE values suggesting the presence of fine-mode scattering aerosols. The mean aerosol radiative forcing near the Yala Glacier region was estimated to be $3.4,-0.5$, and $3.9 \mathrm{~W} \mathrm{~m}^{-2}$ for the TOA, SURF, and ATM, respectively with highest forcing estimated in the pre-monsoon season. The ATM forcing values over rocky, grassy, and snowy surfaces were $3.7,4.1$, and $4.3 \mathrm{~W} \mathrm{~m}^{-2}$, respectively, showing that the maximum forcing occurred above highly reflective surfaces (i.e., those covered by snow or glaciers). Upon analysing the CALIPSO extinction profiles, an elevated layer of aerosol extending up to an altitude of $8 \mathrm{~km}$ in the pre-monsoon season was detected 


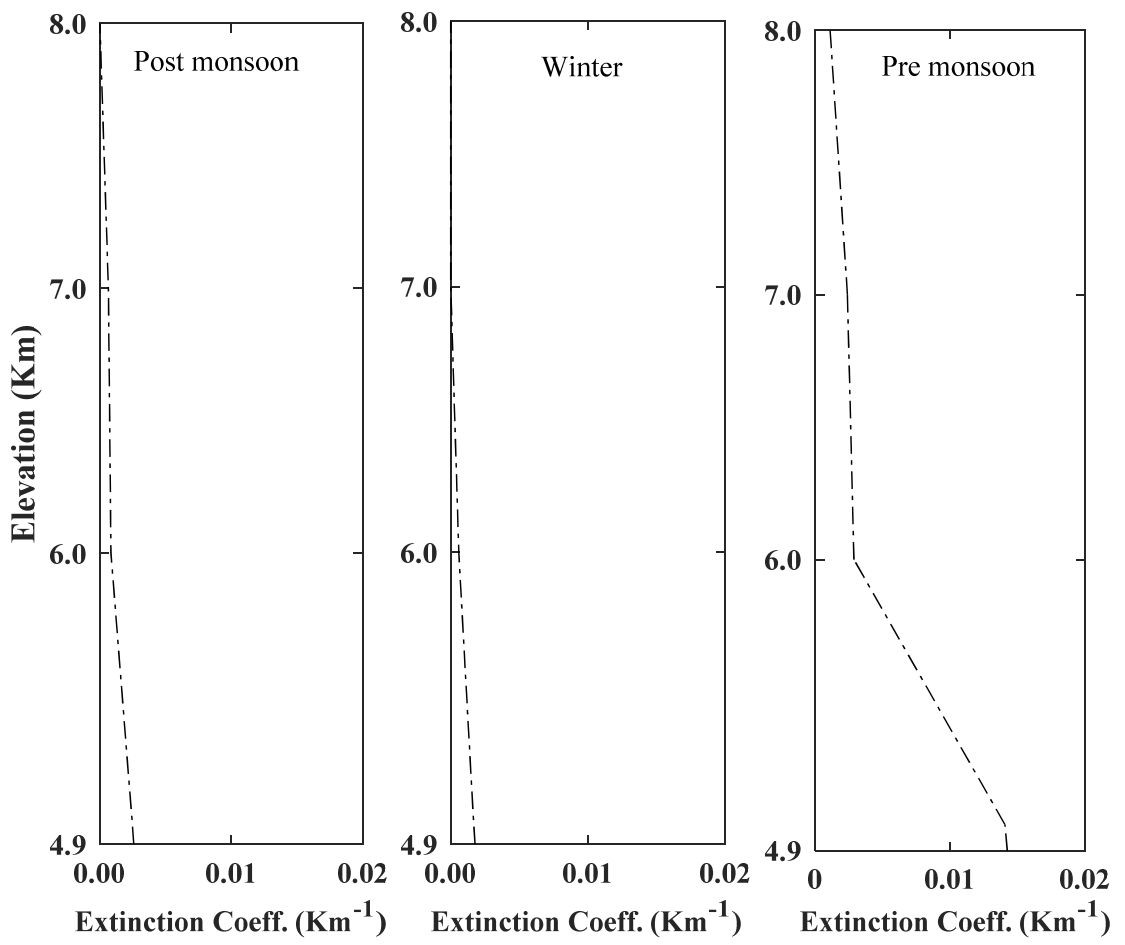

Fig. 11. Monthly mean Lidar extinction profiles at $532 \mathrm{~nm}$ derived from CALIPSO over the Yala Glacier region for postmonsoon, winter and pre-monsoon seasons.
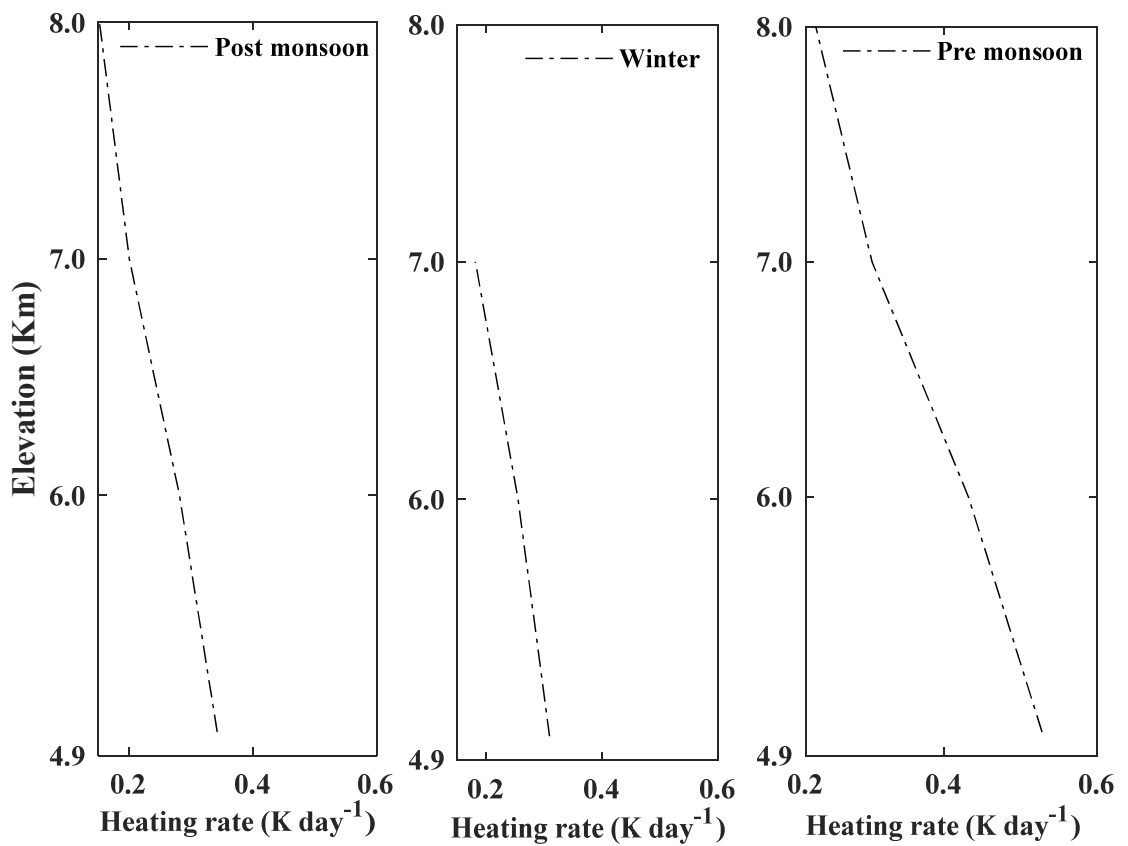

Fig. 12. Elevation wise seasonal heating rate over the Yala Glacier region for post-monsoon, winter and pre-monsoon seasons using SBDART model.

over the study site. Furthermore, the maximum heating rate, $0.375 \pm 0.131 \mathrm{~K} \mathrm{day}^{-1}$, was observed during the premonsoon season, compared to a mean heating rate of 0.268 $\pm 0.117 \mathrm{~K} \mathrm{day}^{-1}$ for the entire study period. Thus, snowcovered surfaces in combination with higher aerosol concentrations increased the ARF and, subsequently, HR values during the pre-monsoon season.

\section{ACKNOWLEDGMENTS}

This study was partially supported by core funds of ICIMOD contributed by the governments of Afghanistan, Australia, Austria, Bangladesh, Bhutan, China, India, Myanmar, Nepal, Norway, Pakistan, Sweden, and Switzerland. The authors would like to thank all those who 
have been directly or indirectly involved in setting up the autonomous BC station. Special thanks go to Dr. Madhavan Bomidi and Saugat Paudel for providing assistance with the OPAC and SBDART model runs. Acknowledgements are also due to Shanuj VC for English editing of the manuscript. Cryosphere Monitoring Project of Kathmandu University (KU), Department of National Parks and Wildlife Conservation (DNPWC) and Department of Environment (DoEnv), Ministry of Forests and Environment, Government of Nepal are duly acknowledged for helping to set up the Yala Black carbon monitoring station and conduct field studies. The MODIS data were obtained via the NASA LAADS DAAC web portal (https://ladsweb.modaps.eosdis. nasa.gov/), while the CALIPSO data were obtained from the Langley Research Center's website (https://eosweb.larc. nasa.gov/). We are equally grateful to NASA's Giovanni web portal (https://giovanni.gsfc.nasa.gov/) and the OMI team. We acknowledge the use of ERA5 data sets downloaded from ECMWF website at https://www.ecmwf. int/en/forecasts/datasets/reanalysis-datasets/era5.

\section{SUPPLEMENTARY MATERIAL}

Supplementary data associated with this article can be found in the online version at http://www.aaqr.org.

\section{REFERENCES}

Ångström, A. (1964). The parameters of atmospheric turbidity. Tellus 16: 64-75.

Babu, S.S., Chaubey, J.P., Krishna Moorthy, K., Gogoi, M.M., Kompalli, S.K., Sreekanth, V., Bagare, S., Bhatt, B.C., Gaur, V.K. and Prabhu, T.P. (2011). High altitude ( $\sim 520 \mathrm{~m}$ amsl) measurements of black carbon aerosols over western trans-himalayas: Seasonal heterogeneity and source apportionment. J. Geophys. Res. 116: D24201.

Babu, S.S., Satheesh, S. and Moorthy, K.K. (2002). Aerosol radiative forcing due to enhanced black carbon at an urban site in India. Geophys. Res. Lett. 29: 1880.

Badarinath, K., Latha, K.M., Chand, T.K., Gupta, P.K., Ghosh, A., Jain, S., Gera, B., Singh, R., Sarkar, A. and Singh, N. (2004). Characterization of aerosols from biomass burning-A case study from Mizoram (Northeast), India. Chemosphere 54: 167-175.

Baltensperger, U., Gäggeler, H., Jost, D., Lugauer, M., Schwikowski, M., Weingartner, E. and Seibert, P. (1997). Aerosol climatology at the high-alpine site jungfraujoch, switzerland. J. Geophys. Res. 102: 19707-19715.

Bikkina, S., Andersson, A., Kirillova, E.N., Holmstrand, H., Tiwari, S., Srivastava, A., Bisht, D. and Gustafsson, Ö. (2019). Air quality in megacity Delhi affected by countryside biomass burning. Nat. Sustainability 2: 200-205.

Bonasoni, P., Laj, P., Marinoni, A., Sprenger, M., Angelini, F., Arduini, J., Bonafè, U., Calzolari, F., Colombo, T. and Decesari, S. (2010). Atmospheric Brown Clouds in the Himalayas: first two years of continuous observations at the Nepal Climate Observatory-Pyramid (5079 m). Atmos. Chem. Phys. 10: 7515-7531.
Bond, T.C. and Bergstrom, R.W. (2006). Light absorption by carbonaceous particles: An investigative review. Aerosol Sci. Technol. 40: 27-67.

Bond, T.C., Doherty, S.J., Fahey, D., Forster, P., Berntsen, T., DeAngelo, B., Flanner, M., Ghan, S., Kärcher, B. and Koch, D. (2013). Bounding the role of black carbon in the climate system: A scientific assessment. $J$. Geophys. Res. 118: 5380-5552.

Carrico, C.M., Bergin, M.H., Shrestha, A.B., Dibb, J.E., Gomes, L. and Harris, J.M. (2003). The importance of carbon and mineral dust to seasonal aerosol properties in the nepal himalaya. Atmos. Environ. 37: 2811-2824.

Chakrabarty, R.K., Garro, M.A., Wilcox, E.M. and Moosmüller, H. (2012). Strong radiative heating due to wintertime black carbon aerosols in the Brahmaputra River Valley. Geophys. Res. Lett. 39: L09804.

Charlson, R.J. and Schwartz, S. (1992). Climate forcing by anthropogenic aerosols. Science 255: 423.

Chen, X., Kang, S., Cong, Z., Yang, J. and Ma, Y. (2018). Concentration, temporal variation, and sources of black carbon in the Mt. Everest region retrieved by real-time observation and simulation. A Atmos. Chem. Phys. 18: 12859-12875.

Chung, C.E. (2012). Aerosol direct radiative forcing: A review. In Atmospheric aerosols-regional characteristicschemistry and physics, InTech.

Cong, Z., Kang, S., Kawamura, K., Liu, B., Wan, X., Wang, Z., Gao, S. and Fu, P. (2015). Carbonaceous aerosols on the south edge of the Tibetan Plateau: concentrations, seasonality and sources. Atmos. Chem. Phys. 15: 15731584.

Cozic, J., Verheggen, B., Mertes, S., Connolly, P., Bower, K., Petzold, A., Baltensperger, U. and Weingartner, E. (2007) Scavenging of black carbon in mixed phase clouds at the high alpine site Jungfraujoch. Atmos. Chem. Phys. 7: 1797-1807.

Dhungel, S., Kathayat, B., Mahata, K. and Panday, A. (2018). Transport of regional pollutants through a remote trans-Himalayan valley in Nepal. Atmos. Chem. Phys. 18: 1203-1216.

Drinovec, L., Močnik, G., Zotter, P., Prévôt, A.S.H., Ruckstuhl, C., Coz, E., Rupakheti, M., Sciare, J., Müller, T., Wiedensohler, A. and Hansen, A.D.A. (2015). The "dual-spot" aethalometer: An improved measurement of aerosol black carbon with real-time loading compensation. Atmos. Meas. Tech. 8: 1965-1979.

Dumka, U.C., Tripathi, S.N., Misra, A., Giles, D.M., Eck, T.F., Sagar, R. and Holben, B.N. (2014). Latitudinal variation of aerosol properties from Indo-Gangetic Plain to central Himalayan foothills during TIGERZ campaign. J. Geophys. Res. 119: 4750-4769.

Dumka, U., Saheb, S.D., Kaskaoutis, D., Kant, Y. and Mitra, D. (2016). Columnar aerosol characteristics and radiative forcing over the Doon Valley in the Shivalik range of northwestern Himalaya. Environ. Sci. Pollut. Res. 23: 25467-25484.

Fialho, P., Freitas, M.C., Barata, F., Vieira, B., Hansen, A. and Honrath, R. (2006). The Aethalometer calibration and determination of iron concentration in dust aerosols. 
J. Aerosol Sci. 37: 1497-1506.

Forster, P., Ramaswamy, V., Artaxo, P., Berntsen, T., Betts, R., Fahey, D.W., Haywood, J., Lean, J., Lowe, D.C., Myhre, G., Nganga, J., Prinn, R., Raga, G., Schulz, M. and Van Dorland, R. (2007). Changes in atmospheric constituents and in radiative forcing. In: Climate Change 2007: The physical science basis. Contribution of Working Group I to the Fourth Assessment Report of the Intergovernmental Panel on Climate Change, Solomon, S., Qin, D., Manning, M., Chen, Z., Marquis, M., Averyt, K.B., Tignor, M. and Miller, H.L. (Eds.), Cambridge University Press, Cambridge, United Kingdom and New York, NY, USA.

Frenzel, B. (1992). Atlas of paleoclimates and paleoenvironments of the northern hemisphere. Geographical Research Institute, Hungarian Academy of SCiences, Budapest, Gustav Fischer Verlag, Stuttgart Jena New York.

Gul, C., Puppala, S.P., Kang, S., Adhikary, B., Zhang, Y., Ali, S., Li, Y. and Li, X. (2018). Concentrations and source regions of light-absorbing particles in snow/ice in northern Pakistan and their impact on snow albedo. Atmos. Chem. Phys. 18: 4981-5000.

Gupta, P., Remer, L.A., Levy, R.C. and Mattoo, S. (2018). Validation of MODIS $3 \mathrm{~km}$ land aerosol optical depth from NASA's EOS Terra and Aqua missions. Atmos. Meas. Tech. 11: 3145-3159.

Hansen, A., Rosen, H. and Novakov, T. (1984). The aethalometer - An instrument for the real-time measurement of optical absorption by aerosol particles. Sci. Total Environ. 36: 191-196.

Haywood, J. and Shine, K. (1995). The effect of anthropogenic sulfate and soot aerosol on the clear sky planetary radiation budget. Geophys. Res. Lett. 22: 603606.

Haywood, J.M., Ramaswamy, V. and Soden, B.J. (1999). Tropospheric aerosol climate forcing in clear-sky satellite observations over the oceans. Science 283: 1299-1303.

Hess, M., Koepke, P. and Schult, I. (1998). Optical properties of aerosols and clouds: The software package OPAC. Bull. Am. Meteorol. Soc. 79: 831-844.

Hoffmann, L., Günther, G., Li, D., Stein, O., Wu, X., Griessbach, S., Heng, Y., Konopka, P., Müller, R. and Vogel, B. (2019). From ERA-Interim to ERA5: the considerable impact of ECMWF's next-generation reanalysis on Lagrangian transport simulations. Atmos. Chem. Phys. 19: 3097-3124.

Howell, S., Clarke, A., Shinozuka, Y., Kapustin, V., McNaughton, C., Huebert, B., Doherty, S. and Anderson, T. (2006). Influence of relative humidity upon pollution and dust during ACE-Asia: Size distributions and implications for optical properties. J. Geophys. Res. 111: D06205.

Immerzeel, W.W., Van Beek, L.P. and Bierkens, M.F. (2010). Climate change will affect the Asian water towers. Science 328: 1382-1385.

Immerzeel, W., Petersen, L., Ragettli, S. and Pellicciotti, F. (2014). The importance of observed gradients of air temperature and precipitation for modeling runoff from a glacierized watershed in the Nepalese Himalayas. Water Resour. Res. 50: 2212-2226.

Kaskaoutis, D., Sinha, P., Vinoj, V., Kosmopoulos, P., Tripathi, S., Misra, A., Sharma, M. and Singh, R. (2013). Aerosol properties and radiative forcing over Kanpur during severe aerosol loading conditions. Atmos. Environ. 79: 7-19.

Kaspari, S., Painter, T., Gysel, M., Skiles, S. and Schwikowski, M. (2014). Seasonal and elevational variations of black carbon and dust in snow and ice in the Solu-Khumbu, Nepal and estimated radiative forcings. Atmos. Chem. Phys. 14: 8089-8103.

Kassianov, E.I., Flynn, C.J., Ackerman, T.P. and Barnard, J.C. (2007). Aerosol single-scattering albedo and asymmetry parameter from MFRSR observations during the ARM Aerosol IOP 2003. Atmos. Chem. Phys. 7: 3341-3351.

Kedia, S., Ramachandran, S., Kumar, A. and Sarin, M. (2010). Spatiotemporal gradients in aerosol radiative forcing and heating rate over Bay of Bengal and Arabian Sea derived on the basis of optical, physical, and chemical properties. J. Geophys. Res. 115: D07205.

Kopacz, M., Mauzerall, D., Wang, J., Leibensperger, E., Henze, D. and Singh, K. (2011). Origin and radiative forcing of black carbon transported to the Himalayas and Tibetan Plateau. Atmos. Chem. Phys. 11: 2837-2852.

Korras-Carraca, M., Hatzianastassiou, N., Matsoukas, C., Gkikas, A. and Papadimas, C. (2015). The regime of aerosol asymmetry parameter over Europe, the Mediterranean and the Middle East based on MODIS satellite data: evaluation against surface AERONET measurements. Atmos. Chem. Phys. 15: 13113-13132.

Kovalev, V.A. and Eichinger, W.E. (2004). Elastic lidar: Theory, practice, and analysis methods. John Wiley \& Sons.

Kumar, A., Singh, N. and Solanki, R. (2018). Evaluation and utilization of MODIS and CALIPSO aerosol retrievals over a complex terrain in Himalaya. Remote Sens. Environ. 206: 139-155.

Levy, R.C., Remer, L.A., Mattoo, S., Vermote, E.F. and Kaufman, Y.J. (2006). A new algorithm for retrieving aerosol properties over land from modis spectral reflectance. NASA Goddard Space Flight Center, 20070017450, Greenbelt, USA.

Liou, K.N. (2002). An introduction to atmospheric radiation. Academic Press, San Diego.

Mahapatra, P., Sinha, P., Boopathy, R., Das, T., Mohanty, S., Sahu, S. and Gurjar, B. (2018). Seasonal progression of atmospheric particulate matter over an urban coastal region in peninsular India: Role of local meteorology and long-range transport. Atmos. Res. 199: 145-158.

Marcq, S., Laj, P., Roger, J.C., Villani, P., Sellegri, K., Bonasoni, P., Marinoni, A., Cristofanelli, P., Verza, G. and Bergin, M. (2010). Aerosol optical properties and radiative forcing in the high Himalaya based on measurements at the Nepal Climate Observatory-Pyramid site $(5079 \mathrm{~m}$ a.s.1.). Atmos. Chem. Phys. 10: 5859-5872.

Marinoni, A., Cristofanelli, P., Laj, P., Duchi, R., Calzolari, F., Decesari, S., Sellegri, K., Vuillermoz, E., 
Verza, G. and Villani, P. (2010). Aerosol mass and black carbon concentrations, a two year record at NCO-P (5079 m, Southern Himalayas). Atmos. Chem. Phys. 10: 8551-8562.

Marinoni, A., Cristofanelli, P., Laj, P., Duchi, R., Putero, D., Calzolari, F., Landi, T., Vuillermoz, E., Maione, M. and Bonasoni, P. (2013). High black carbon and ozone concentrations during pollution transport in the Himalayas: Five years of continuous observations at NCO-P global GAW station. J. Environ. Sci. 25: 1618-1625.

Moorthy, K.K., Babu, S.S. and Satheesh, S. (2005). Aerosol characteristics and radiative impacts over the Arabian Sea during the intermonsoon season: Results from armex field campaign. J. Atmos. Sci. 62: 192-206.

Nair, V.S., Babu, S.S., Moorthy, K.K., Sharma, A.K., Marinoni, A. and Ajai (2013). Black carbon aerosols over the Himalayas: Direct and surface albedo forcing. Tellus B 65: 19738.

Nessler, R., Weingartner, E. and Baltensperger, U. (2005). Effect of humidity on aerosol light absorption and its implications for extinction and the single scattering albedo illustrated for a site in the lower free troposphere. J. Aerosol Sci. 36: 958-972.

Nichol, J. and Bilal, M. (2016). Validation of MODIS 3 $\mathrm{km}$ resolution aerosol optical depth retrievals over Asia. Remote Sens. 8: 328.

Ningombam, S.S., Bagare, S., Srivastava, A., Sohn, B., Song, H.J. and Larson, E. (2014). Aerosol radiative forcing over a high-altitude station Merak, in the transHimalayan region during advection of anthropogenic events from the Indo-Gangetic Plain. Atmos. Environ. 98: 253-259.

Panicker, A., Pandithurai, G., Safai, P., Dipu, S. and Lee, D.I. (2010). On the contribution of black carbon to the composite aerosol radiative forcing over an urban environment. Atmos. Environ. 44: 3066-3070.

Pant, P., Hegde, P., Dumka, U., Sagar, R., Satheesh, S., Moorthy, K.K., Saha, A. and Srivastava, M. (2006). Aerosol characteristics at a high-altitude location in central Himalayas: Optical properties and radiative forcing. J. Geophys. Res. 111: D17206.

Patel, P.N. and Kumar, R. (2015). Estimation of aerosol characteristics and radiative forcing during dust events over dehradun. Aerosol Air Qual. Res 15: 2082-2093.

Pathak, B., Kalita, G., Bhuyan, K., Bhuyan, P. and Moorthy, K.K. (2010). Aerosol temporal characteristics and its impact on shortwave radiative forcing at a location in the northeast of India. J. Geophys. Res. 115: D19204.

Pradhananga, N.S., Kayastha, R.B., Bhattarai, B.C., Adhikari, T.R., Pradhan, S.C., Devkota, L.P., Shrestha, A.B. and Mool, P.K. (2014). Estimation of discharge from Langtang River basin, Rasuwa, Nepal, using a glacio-hydrological model. Ann. Glaciol. 55: 223-230.

Praveen, P.S., Ahmed, T., Kar, A., Rehman, I.H. and Ramanathan, V. (2012). Link between local scale BC emissions in the Indo-Gangetic Plains and large scale atmospheric solar absorption. Atmos. Chem. Phys. 12: 1173-1187.
Raju, M., Safai, P., Vijayakumar, K., Devara, P., Naidu, C., Rao, P. and Pandithurai, G. (2016). Atmospheric abundances of black carbon aerosols and their radiative impact over an urban and a rural site in SW India. Atmos. Environ. 125: 429-436.

Ram, K. and Sarin, M. (2009). bsorption coefficient and site-specific mass absorption efficiency of elemental carbon in aerosols over urban, rural, and high-altitude sites in India. Environ. Sci. Technol. 43: 8233-8239.

Ram, K., Sarin, M. and Hegde, P. (2010). Long-term record of aerosol optical properties and chemical composition from a high-altitude site (Manora Peak) in Central Himalaya. Atmos. Chem. Phys. 10: 11791-11803.

Ramachandran, S. and Kedia, S. (2010). Black carbon aerosols over an urban region: Radiative forcing and climate impact. J. Geophys. Res. 115: D10202.

Ramaswamy, V., Boucher, O., Haigh, J., Hauglustaine, D., Haywood, J., Myhre, G., Nakajima, T., Shi, G., Solomon, S. and Betts, R.E. (2001). Radiative forcing of climate change, Pacific Northwest National Laboratory (PNNL), Richland, WA (US).

Ramanathan, V. and Carmichael, G. (2008). Global and regional climate changes due to black carbon. Nat. Geosci. 1: 221.

Remer, L., Mattoo, S., Levy, R. and Munchak, L. (2013). Modis $3 \mathrm{~km}$ aerosol product: Algorithm and global perspective. Atmos. Meas. Tech. 6: 1829.

Ricchiazzi, P., Yang, S., Gautier, C. and Sowle, D. (1998). SBDART: A research and teaching software tool for plane-parallel radiative transfer in the Earth's atmosphere. Bull. Am. Meteorol. Soc. 79: 2101-2114.

Rupakheti, D., Adhikary, B., Praveen, P.S., Rupakheti, M., Kang, S., Mahata, K.S., Naja, M., Zhang, Q., Panday, A.K. and Lawrence, M.G. (2017). Pre-monsoon air quality over Lumbini, a world heritage site along the Himalayan foothills. Atmos. Chem. Phys. 17: 1104111063.

Satheesh, S., Moorthy, K.K., Babu, S.S., Vinoj, V. and Dutt, C. (2008). Climate implications of large warming by elevated aerosol over India. Geophys. Res. Lett. 35: L19809.

Schmale, J., Flanner, M., Kang, S., Sprenger, M., Zhang, Q., Guo, J., Li, Y., Schwikowski, M. and Farinotti, D. (2017). Modulation of snow reflectance and snowmelt from Central Asian glaciers by anthropogenic black carbon. Sci. Rep. 7: 40501.

Schmid, O., Artaxo, P., Arnott, W., Chand, D., Gatti, L.V., Frank, G., Hoffer, A., Schnaiter, M. and Andreae, M. (2006). Spectral light absorption by ambient aerosols influenced by biomass burning in the Amazon Basin. I: Comparison and field calibration of absorption measurement techniques. Atmos. Chem. Phys. 6: 34433462.

Schuster, G.L., Dubovik, O. and Holben, B.N. (2006). Angstrom exponent and bimodal aerosol size distributions. J. Geophys. Res. 111: D07207.

Sen, A., Abdelmaksoud, A., Ahammed, Y.N., Banerjee, T., Bhat, M.A., Chatterjee, A., Choudhuri, A.K., Das, T., Dhir, A. and Dhyani, P.P. (2017). Variations in 
particulate matter over Indo-Gangetic Plains and IndoHimalayan Range during four field campaigns in winter monsoon and summer monsoon: Role of pollution pathways. Atmos. Environ. 154: 200-224.

Shea, J.M., Wagnon, P., Immerzeel, W.W., Biron, R., Brun, F. and Pellicciotti, F. (2015). A comparative highaltitude meteorological analysis from three catchments in the Nepalese Himalaya. Int. J. Water Resour. Dev. 31: 174-200.

Srivastava, A., Ram, K., Pant, P., Hegde, P. and Joshi, H. (2012). Black carbon aerosols over Manora Peak in the Indian Himalayan foothills: Implications for climate forcing. Environ. Res. Lett 7: 014002.

Stamnes, K., Tsay, S.C., Wiscombe, W. and Laszlo, I. (2000). DISORT, a general-purpose Fortran program for discrete-ordinate-method radiative transfer in scattering and emitting layered media: Documentation of methodology. Goddard Space Flight Center, NASA.

Surendran, D.E., Beig, G., Ghude, S.D., Panicker, A., Manoj, M., Chate, D. and Ali, K. (2013). Radiative forcing of black carbon over Delhi. Int. J. Photoenergy 2013: 313652 .

Titos, G., Lyamani, H., Cazorla, A., Sorribas, M., FoyoMoreno, I., Wiedensohler, A. and Alados-Arboledas, L. (2014). Study of the relative humidity dependence of aerosol light-scattering in southern Spain. Tellus $B$ 66: 24536.

Twomey, S. (1977). The influence of pollution on the shortwave albedo of clouds. J. Atmos. Sci. 34: 11491152.

Ueno, K., Toyotsu, K., Bertolani, L. and Tartari, G. (2008). Stepwise onset of monsoon weather observed in the Nepal Himalaya. Mon. Weather Rev. 136: 25072522.

Verma, N., Bagare, S., Ningombam, S.S. and Singh, R.B. (2010). Aerosol optical properties retrieved using Skyradiometer at Hanle in western Himalayas. J. Atmos. Sol. Terr. Phys. 72: 115-124.

Vinoj, V., Babu, S.S., Satheesh, S., Moorthy, K. and Kaufman, Y. (2004). Radiative forcing by aerosols over the Bay of Bengal region derived from shipborne, island-based, and satellite (Moderate-Resolution Imaging Spectroradiometer) observations. J. Geophys. Res. 109: D05203.

Vinoj, V., Satheesh, S. and Moorthy, K.K. (2010). Optical, radiative, and source characteristics of aerosols at Minicoy, a remote island in the southern Arabian Sea. $J$. Geophys. Res. 115: D01201.

Viviroli, D., Dürr, H.H., Messerli, B., Meybeck, M. and Weingartner, R. (2007). Mountains of the world, water towers for humanity: Typology, mapping, and global significance. Water Resour. Res. 43: W07447.

von Engeln, A. and Teixeira, J. (2013). A planetary boundary layer height climatology derived from ECMWF reanalysis data. J. Clim. 26: 6575-6590.

Voogt, J.A. and Oke, T. (1998). Effects of urban surface geometry on remotely-sensed surface temperature. Int. J. Remote Sens. 19: 895-920.

Wang, M., Xu, B., Wang, N., Cao, J., Tie, X., Wang, H., Zhu, C. and Yang, W. (2016). Two distinct patterns of seasonal variation of airborne black carbon over Tibetan Plateau. Sci. Total Environ. 573: 1041-1052.

Whiteman, C.D. (2000). Mountain meteorology: Fundamentals and applications. Oxford University Press, New York.

Wiscombe, W. and Grams, G. (1976). The backscattered fraction in two-stream approximations. J. Atmos. Sci. 33: 2440-2451.

Zalakeviciute, R., López-Villada, J. and Rybarczyk, Y. (2018). Contrasted effects of relative humidity and precipitation on urban $\mathrm{PM}_{2.5}$ pollution in high elevation urban areas. Sustainability 10: 2064.

Zhao, S., Ming, J., Xiao, C., Sun, W. and Qin, X. (2012). A preliminary study on measurements of black carbon in the atmosphere of northwest Qilian Shan. J. Environ. Sci. 24: 152-159.

Received for review, September 14, 2018

Revised, June 7, 2019 Accepted, June 18, 2019 